\title{
Fission Product Volatility and Off-Gas Systems for Molten Salt Reactors
}

Nuclear Technology

Research and Development

Prepared for U.S. Department of Energy

J. McFarlane, (a) N. D. Bull Ezell, (a) G. D. DelCul, (a) D. E. Holcomb, (a) K. Myhre, (a) A. Lines, (b) S. Bryan, (b) H. Felmy, ${ }^{(\mathrm{b})}$ and B. J. Riley (b) (a) Oak Ridge National Laboratory (b) Pacific Northwest National Laboratory August 2019

ORNL/TM-2019/1266

PNNL-28974 



\section{DISCLAIMER}

This information was prepared as an account of work sponsored by an agency of the U.S. Government. Neither the U.S. Government nor any agency thereof, nor any of their employees, makes any warranty, expressed or implied, or assumes any legal liability or responsibility for the accuracy, completeness, or usefulness, of any information, apparatus, product, or process disclosed, or represents that its use would not infringe privately owned rights. References herein to any specific commercial product, process, or service by trade name, trade mark, manufacturer, or otherwise, does not necessarily constitute or imply its endorsement, recommendation, or favoring by the U.S. Government or any agency thereof. The views and opinions of authors expressed herein do not necessarily state or reflect those of the U.S. Government or any agency thereof. 



\section{SUMMARY}

The overall objective of the Department of Energy investigation into off-gas technology for molten salt reactors (MSR)s is to develop a list of functional requirements for an effective and reliable system. In collaboration with other elements of the Advanced Reactor Campaign (denoted in italics), the off-gas work package will address the following questions:

1. What is the composition of the gas stream going to the off-gas system (chemistry and source term work package)?

2. What is the function of each off-gas treatment component, and how do they work? How efficient are they at removing or delaying fission and activation products?

3. What are the maintenance requirements of the off-gas system?

4. Is the system able to effectively detect and respond to off-normal events (off-gas, source term, and simulation work packages)?

5. What measurement capabilities are possible now? What are the gaps?

The objective of the off-gas project in fiscal year 2019 was to address the second, fourth, and fifth questions above. Thus, project has proceeded along two fronts: one focused on scrubber development at Oak Ridge National Laboratory and the other focused on spectroscopic detection of simulant fission product iodine at Pacific Northwest National Laboratory.

A molten hydroxide scrubber was proposed for removal of both acidic gases, entrained mists, and particulates from a sparged molten salt off-gas. Hydroxide solutions are well known for their scrubbing ability and have been used in the off-gas systems of salt processing facilities. For the current project, a $\mathrm{NaOH}-\mathrm{KOH}$ eutectic is being evaluated as a gettering medium. A laboratory-scale prototype glass scrubber was designed and built for the removal of aerosol simulants. The glass allows visualization of the scrubber operation, which is important for designing the stainless-steel housing for the $\mathrm{NaOH}-\mathrm{KOH}$ eutectic.

In parallel, Pacific Northwest National Laboratory has been developing optical sensors for detecting fission products and aerosol or mist species that could be entrained in the off-gas flow of an MSR. Efforts include Raman spectroscopy to identify and quantify iodine species such as $\mathrm{I}_{2}$ and ICl and laser-induced breakdown spectroscopy and laser-induced fluorescence for mists. Next year, these optical methods will be added to the hydroxide scrubber instrumentation to determine its effectiveness against airborne vapors and mists of concern. 


\section{CONTENTS}

SUMMARY iii

ACRONYMS AND ABBREVIATIONS. viii

1. INTRODUCTION

1.1 Fission and activation product volatility and release into the headspace of operating MSRs.

1.2 Off-gas systems for MSRs and other molten salt operations ................................................

1.3 Detection and monitoring of fission and activation products (including tritium), sensor systems

2. FY 2019 EXPERIMENTAL PROGRAM

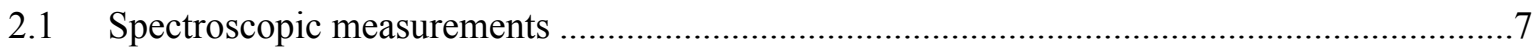

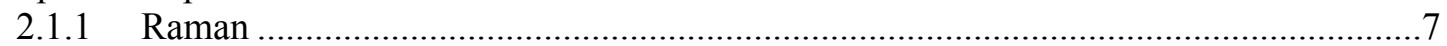

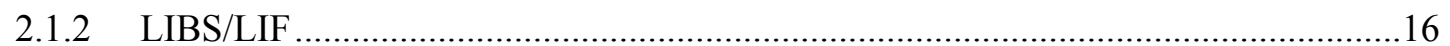

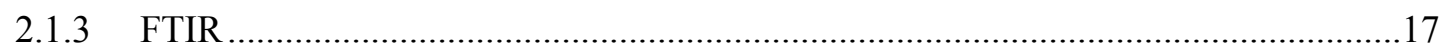

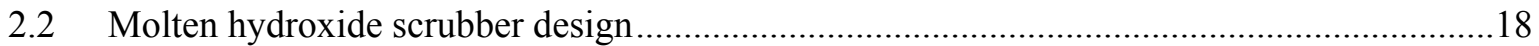

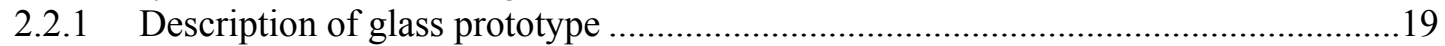

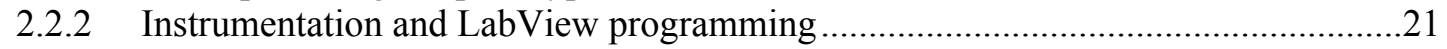

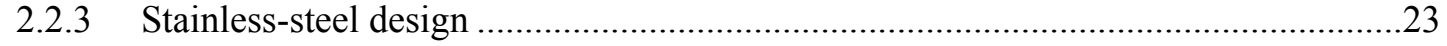

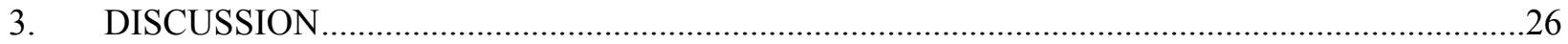

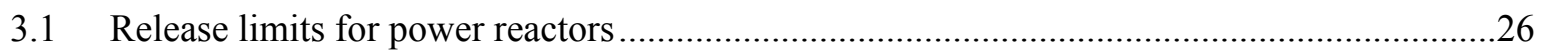

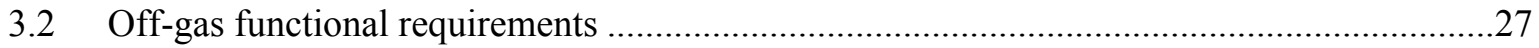

3.3 Progress toward conceptual design of an off-gas system................................................28

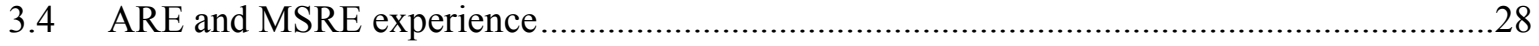

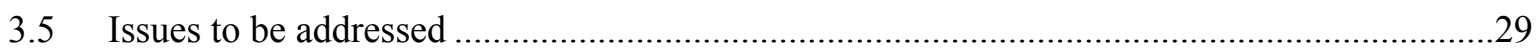

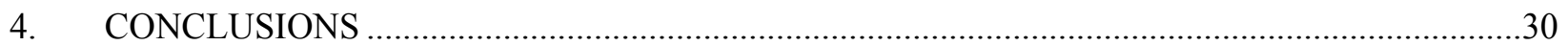

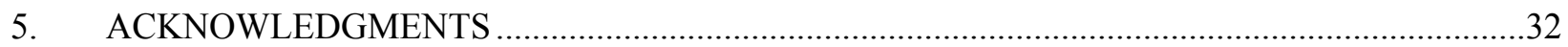

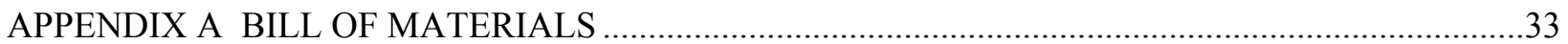

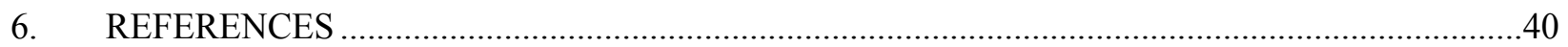




\section{FIGURES}

Figure 1 Activity of fission-product isotopes of xenon and krypton in MSRE off-gas stream. Image reproduced from ORNL-TM-728. ${ }^{3}$

Figure 2. Schematic of the overall off-gas system for a commercial MSR based on the MSRE experience. All of the components shown, except the molten hydroxide packed-bed scrubber, are commercially available.

Figure 3. Schematic of lab setup for testing of glass prototype scrubber. ..............................................6

Figure 4. Schematic of lab setup for testing of molten hydroxide scrubber. .............................................

Figure 5. Schematic of the Raman signature collection system. ..........................................................

Figure 6. Spectral signatures observed for the $\mathrm{I}_{2}$ systems using both the 671 and $532 \mathrm{~nm}$ Raman systems. The spectral traces are red and green respectively, according to the excitation wavelength, with the lower -intensity green trace offset in the positive y-direction from the red.

Figure 7. Spectral signatures observed for $\mathrm{I}_{2}$ at $25^{\circ} \mathrm{C}$ while stepping pressure from 0 to $33 \mathrm{~Pa}$ using the $532 \mathrm{~nm}$ laser system.

Figure 8. Spectral signatures observed for $\mathrm{I}_{2}$ using the $671 \mathrm{~nm}$ laser system. Two unique spectral fingerprints were identified, which indicates two separate species of $\mathrm{I}_{2}$ are present within the gas system.

Figure 9. Signatures of $\mathrm{ICl}$ obtained using the $532 \mathrm{~nm}$ Raman system (top) with a comparison to literature values from Holzer et al. (1970) (bottom). Reproduced with permission from J. Chem. Phys. 52, 399 (1970). Copyright 1970, American Institute of Physics.

Figure 10. Calibration curves showing relationship of Raman signal intensity to $\mathrm{I}_{2}$ pressure at multiple temperatures for the 532 (top) and $671 \mathrm{~nm}$ (bottom) laser systems.

Figure 11. Optical sampling geometry for off-gas aerosol using LIBS.

Figure 12. The infrared spectrum of ICl showing the P-and R-branch of the fundamental vibrational band. The spectrum was measured using a Bruker FTIR system at $2 \mathrm{~cm}^{-1}$ resolution.

Figure 13. The molten hydroxide scrubber glass prototype showing the piston pump on the left and a higher magnification view of the fluid flow through the packed bed on the right

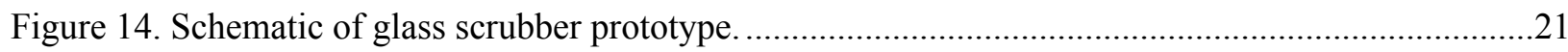

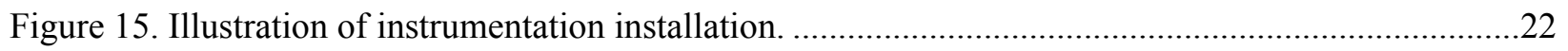

Figure 16. Screenshot of LabVIEW user interface for off-gas monitoring instrumentation......................23

Figure 17. Image from measurement computer website for USB-2408 acquisition device......................23

Figure 18. Stainless-steel scrubber design based on engineering flow calculations..................................24 


\section{TABLES}

Table 1. Summary of volatile off-gas waste components that will or could require capture and/or immobilization.

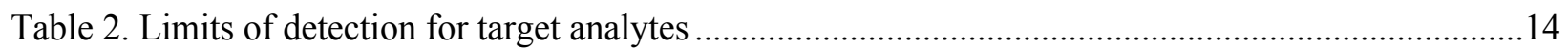

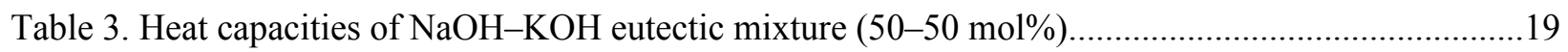

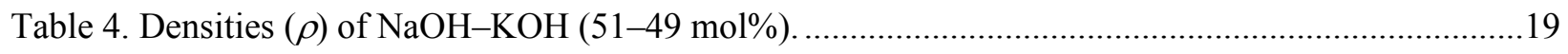

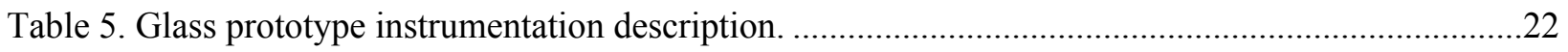

Table 6. Engineering calculations column diameter for $15 \mathrm{~mm}$ size packing. .........................................25 


\section{ACRONYMS AND ABBREVIATIONS}

$\begin{array}{ll}\text { AgZ } & \text { silver mordenite } \\ \text { ARE } & \text { Aircraft Reactor Experiment } \\ \text { CFR } & \text { Code of Federal Regulations } \\ \text { HEPA } & \text { high-efficiency particulate air (filter) } \\ \text { LIBS } & \text { laser-induced ablation spectroscopy } \\ \text { LIF } & \text { laser-induced fluorescence } \\ \text { LOD } & \text { limit of detection } \\ \text { MSBR } & \text { molten salt breeder reactor } \\ \text { MSR } & \text { molten salt reactor } \\ \text { MSRE } & \text { Molten Salt Reactor Experiment } \\ \text { ORNL } & \text { Oak Ridge National Laboratory } \\ \text { PNNL } & \text { Pacific Northwest National Laboratory } \\ \text { WF } & \text { waste form }\end{array}$





\section{INTRODUCTION}

An effective off-gas processing system is important for molten salt reactor (MSR) operation; consequently, the Department of Energy, Office of Nuclear Energy's Advanced Reactor Campaign is supporting the development of an off-gas system for a generic molten salt reactor. The system will couple to the headspace of the reactor core that will contain volatile fission products, activation products, particulates, and mists generated from the movement of the salt through the primary heat transport system. The fuel salt may also be sparged with an inert gas, such as helium, to liberate entrained fission products or poisons from the reactor. The gases will be highly radioactive, and this is anticipated to constitute a substantial heat load (a few tens of megawatts for a large reactor). Thus, the system will need to be designed to provide cooling during normal operations and passive decay heat removal in the event of a loss of forced cooling accident. Thus, the mass load of salt constituents into the off-gas system will be determined by the thermochemical and thermophysical properties of the salt and the transport of fluids through the reactor. Additionally, the salt vapors and mists may condense/solidify on the surfaces within the system. Consequently, a final system will need to provide the capability to remove deposited solids from its surfaces. The off-gas handling system may also require a secondary containment layer to accomplish its radionuclide containment safety function with adequate reliability.

The off-gas program is conceptualizing a system for detecting and capturing fission and activation products that will accumulate in the headspace of an MSR. Inputs into the headspace will come from reactor physics calculations and thermochemical speciation, which are being investigated through other areas of the MSR campaign. Limitations on off-gas system performance and radionuclide leakage are based upon applying the advanced reactor expectation of enhanced margins of safety compared to existing light water reactors according to the existing rules in the Code of Federal Regulations (CFR). ${ }^{1}$

\subsection{Fission and activation product volatility and release into the headspace of operating MSRs}

The purpose of this section is to provide an overview of options that could be used to treat off-gas effluents from an MSR; the reader is referred to a more comprehensive overview provided in a previous document. ${ }^{2}$ Based on the Molten Salt Reactor Experiment (MSRE) experience, we should expect the following contaminants to be treated by the off-gas system of a commercial MSR (fluoride or chloride systems alike):

1) Mists, aerosols, and particles (e.g., pyrolysis products, salt residues, graphite debris for graphite moderated fluoride systems, noble metals)

2) Volatile species (e.g., $\mathrm{Kr}, \mathrm{Xe},{ }^{3} \mathrm{HF}, \mathrm{HF}, \mathrm{H}_{2} \mathrm{O}, \mathrm{O}_{2}, \mathrm{~F}_{2}, \mathrm{Cl}_{2}, \mathrm{Br}_{2}, \mathrm{I}_{2}, \mathrm{Ar}$, interhalogens, volatile halides) and the decay products (e.g., $\mathrm{Cs}, \mathrm{Ba}, \mathrm{Rb}, \mathrm{Sr}, \mathrm{La}, \mathrm{Br}, \mathrm{I}, \mathrm{Se}, \mathrm{Te}$ )

3) Tritium (e.g., ${ }^{3} \mathrm{H}_{2(\mathrm{~g})},{ }^{3} \mathrm{HH}_{(\mathrm{g})},{ }^{3} \mathrm{HF}_{(\mathrm{g})},{ }^{3} \mathrm{HF}_{(\mathrm{l})}$, and possibly ${ }^{3} \mathrm{HHO}_{(\mathrm{g})}$ and ${ }^{3} \mathrm{H}_{2} \mathrm{O}_{(\mathrm{g})}$ )

4) Short-lived volatile radionuclides and their daughters (e.g., ${ }^{139} \mathrm{Xe} t_{1 / 2}=39.5 \mathrm{~s},{ }^{90} \mathrm{Kr} t_{1 / 2}=32.3 \mathrm{~s},{ }^{137} \mathrm{Xe}$ $t_{1 / 2}=3.83 \mathrm{~min} .,{ }^{135 \mathrm{~m} X e ~} t_{1 / 2}=15.3 \mathrm{~min} .,{ }^{89} \mathrm{Kr} t_{1 / 2}=3.18 \mathrm{~min} .,{ }^{135} \mathrm{Xe} t_{1 / 2}=9.1 \mathrm{~h},{ }^{88} \mathrm{Kr} t_{1 / 2}=2.84 \mathrm{~h},{ }^{133 \mathrm{~m} X \mathrm{e}}$ $\left.t_{1 / 2}=2.19 \mathrm{~d},{ }^{133} \mathrm{Xe} t_{1 / 2}=5.25 \mathrm{~d}\right)$

5) Longer-lived radionuclides (e.g., ${ }^{85} \mathrm{Kr} t_{1 / 2}=10.7 \mathrm{y},{ }^{36} \mathrm{Cl} t_{1 / 2}=3 \times 10^{5} \mathrm{y},{ }^{79} \mathrm{Se} t_{1 / 2}=6.5 \times 10^{4} \mathrm{y}$, $\left.{ }^{129} t_{1 / 2}=1.57 \times 10^{7} \mathrm{y}\right)$

The MSRE xenon and krypton isotope concentrations in the off-gas system are shown in Figure $1 .^{3}$ 


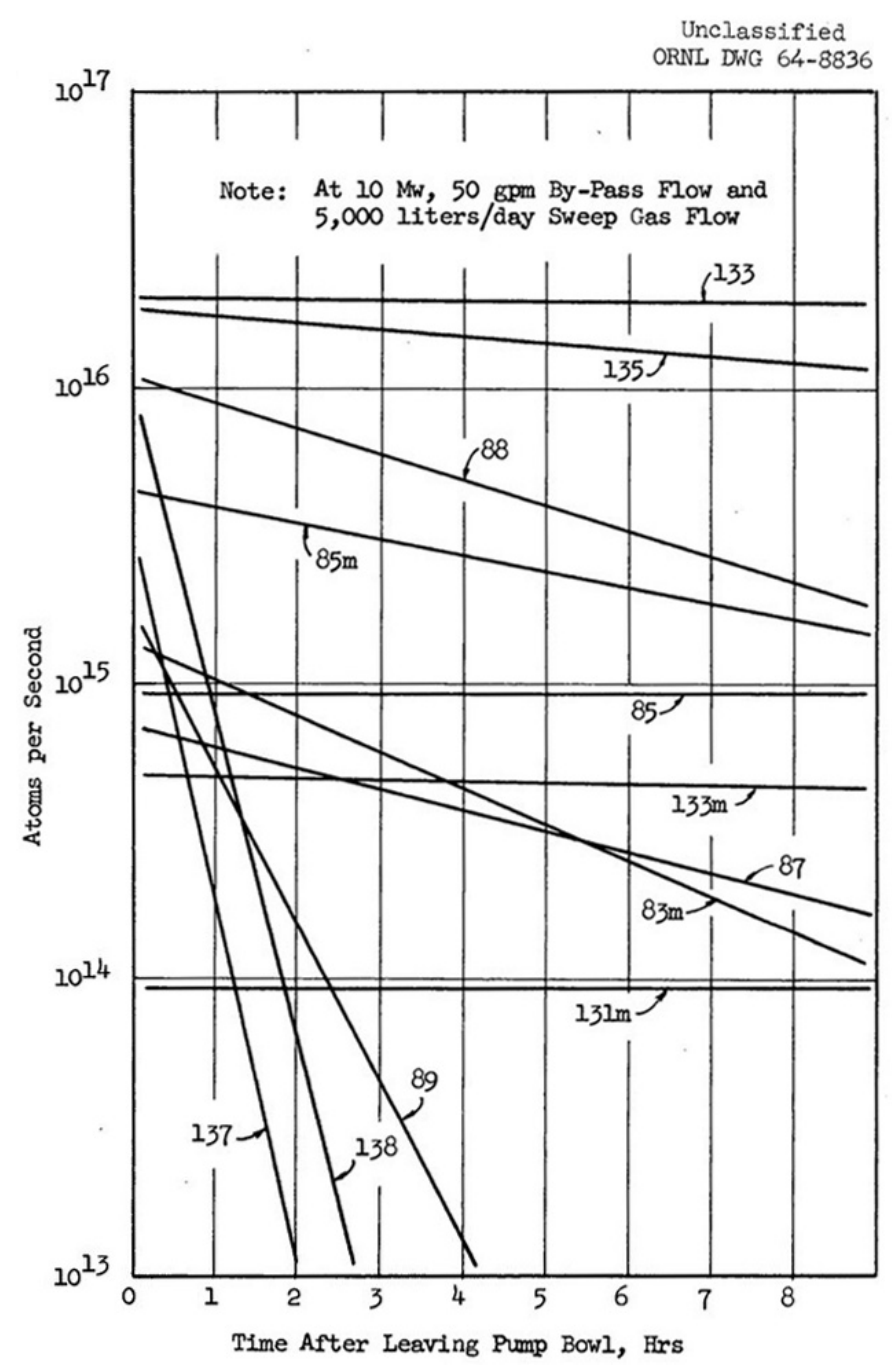

Figure 1 Activity of fission-product isotopes of xenon and krypton in MSRE off-gas stream. Image reproduced from ORNL-TM-728. ${ }^{3}$

A summary of potential options for processing various streams is presented in Table 1 for the variety of materials that may be entrained in the headspace of an MSR. For some of these species, several capture methods are available, but for others, such as $\mathrm{N}_{2}$ and $\mathrm{O}_{2}$, few alternatives exist. The complete off-gas system will include several options, with the carrier gas flowing from one unit to the next. 
Table 1. Summary of volatile off-gas waste components that will or could require capture and/or immobilization.

\begin{tabular}{|c|c|c|c|}
\hline Waste type & Capture method & Immobilization method & Reference \\
\hline \multirow{2}{*}{ Particulates } & Molten $\mathrm{NaOH}$ & $\begin{array}{l}\text { Ceramic or glass waste } \\
\text { form (WF) }\end{array}$ & Smith $(1956)^{4}$ \\
\hline & HEPA filters ( $\geq 300 \mathrm{~nm}$ diameter) & $\begin{array}{l}\text { Size reduction and } \\
\text { decontamination }\end{array}$ & IAEA $(1987)^{5}$ \\
\hline \multirow{3}{*}{ Aerosols* } & Molten $\mathrm{NaOH}$ & Ceramic or glass WF & Smith (1956) \\
\hline & Particle traps, charcoal beds & Solids & $\begin{array}{l}\text { Robertson }(1965)^{6} \\
\text { Zagnit'ko and Chuvilin } \\
(2009)^{7}\end{array}$ \\
\hline & HEPA filters & $\begin{array}{l}\text { Size reduction and } \\
\text { decontamination }\end{array}$ & IAEA (1987) \\
\hline Reactive gases & Molten $\mathrm{NaOH}$ & Ceramic or glass WF & Smith (1956) \\
\hline $\begin{array}{l}\text { Tritium } \\
\text { (i.e., }{ }^{3} \mathrm{H}_{(\mathrm{g})} \\
\left.{ }^{3} \mathrm{H}_{2} \mathrm{O}\right)\end{array}$ & $\begin{array}{l}\text { Separated from low-volume gas } \\
\text { or high-volume water streams } \\
\text { (e.g., desiccant, molecular sieve, } \\
\text { carbon) }\end{array}$ & $\begin{array}{l}\text { Low-water cement in high- } \\
\text { integrity containers }\end{array}$ & Vienna et al. $(2015 a)^{8}$ \\
\hline \multirow{5}{*}{$\begin{array}{l}\text { Residual } \\
\text { halides (e.g., F, } \\
\mathrm{Cl}, \mathrm{I} \text { ) }\end{array}$} & Silver mordenite (AgZ) & As AgI in composite WF & Bruffey et al. $(2016)^{9}$ \\
\hline & $\mathrm{Ag}^{0}$-functionalized silica aerogel & As AgI in composite WF & Matyáš et al. $(2011)^{10}$ \\
\hline & $\begin{array}{l}\mathrm{Ag}^{+/ 0} \text {-loaded aluminosilicate } \\
\text { aerogels }\end{array}$ & As AgI in composite WF & Riley et al. $(2017 \mathrm{a})^{11}$ \\
\hline & Sulfide aerogel (chalcogel) & In chalcogenide glass & $\begin{array}{l}\text { Riley et al. (2013a); }{ }^{12} \\
\text { Riley et al. }(2015)^{13}\end{array}$ \\
\hline & Molten $\mathrm{NaOH}$ & Ceramic or glass WF & Smith (1956) \\
\hline $\mathrm{N}_{2}, \mathrm{O}_{2}^{\dagger}$ & $\begin{array}{l}\text { Activated carbon, magnetic } \\
\text { separation, cryogenic }\end{array}$ & Released & Baker et al. $(2007)^{14}$ \\
\hline \multirow{4}{*}{$\begin{array}{l}\text { Noble gases } \\
\text { (e.g., Kr, Xe) }\end{array}$} & Cryogenic distillation & Storage as compressed gas & Liu et al. $(2014 a)^{15}$ \\
\hline & $\begin{array}{l}\text { Solid sorbents }(\mathrm{AgZ}, \mathrm{HZ}, \\
\text { activated charcoal) }\end{array}$ & Storage as compressed gas & Vienna et al. (2015a) \\
\hline & Metal-organic frameworks & Storage as compressed gas & Liu et al. (2014a) \\
\hline & Sulfide aerogel (chalcogel) & Storage as compressed gas & $\begin{array}{l}\text { Subrahmanyam et al. } \\
(2017)^{16}\end{array}$ \\
\hline
\end{tabular}

Note: $\mathrm{HEPA}=$ high-efficiency particulate air filter, $\mathrm{WF}=$ waste form.

${ }^{*}$ Full salt composition from splashes, or condensation of volatile daughters

TNote that the isotopes generated from a fluoride salt are ${ }^{16} \mathrm{O},{ }^{17} \mathrm{O}$, and ${ }^{18} \mathrm{O}$ for oxygen and ${ }^{15} \mathrm{~N}$ for nitrogen, which are all stable; thus these could be released.

\subsection{Off-gas systems for MSRs and other molten salt operations}

Operational experience with MSRs is limited to the MSRE, which provided substantial information to support the conceptual design for the larger molten salt breeder reactor (MSBR), which was never finalized. ${ }^{17}$ In the MSBR design, helium bubbles were injected into a slip stream of salt that would comprise about $10 \%$ of the total flow of fuel salt, with the goal of stripping fission gases and other contaminants. The salt passed through a gas separator located upstream of the bubble generator. The gas that contacted the salt passed through a fuel salt drain tank, where a residence time of 1-2 hours allows most of the entrained salt particulates and contaminants to settle before passing to the off-gas system. The off-gas system relied on charcoal beds, in which radionuclides can decay for 90 days, leaving ${ }^{85} \mathrm{Kr}$ as the most important contributor to the source term. The helium gas was cleaned and returned to the purge system. 
Another option for cleaning salts is a molten hydroxide scrubber, which was the concept examined in this project. A combined gravitational/alkaline scrubbing system should remove mist, aerosol, particles, and reactive species including long-lived ${ }^{36} \mathrm{Cl}\left(t_{1 / 2}=3 \times 10^{5} \mathrm{y}\right),{ }^{79} \mathrm{Se}\left(t_{1 / 2}=6.5 \times 10^{4} \mathrm{y}\right)$, and ${ }^{129} \mathrm{I}$

$\left(t_{1 / 2}=1.6 \times 10^{7} \mathrm{y}\right)$. Any tritium present as $\mathrm{HF}$ in molten fluoride reactors, and probably as ${ }^{3} \mathrm{HCl}$ in chloride systems, will be transformed into $\mathrm{H}_{2} \mathrm{O}$ by the hydroxide scrubber ${ }^{18}$ and released into the flowing He along with unreactive gaseous species such as $\mathrm{N}_{2}, \mathrm{O}_{2}, \mathrm{Ar}, \mathrm{Kr}$, and $\mathrm{Xe}$. The removal of these species will require additional systems. The schematic provided in Figure 2 shows a combined system that will treat and remove all of the contaminants from the He cover, allowing for it to be recycled back into the reactor vessel. The system proposed in Figure 2 includes the following components:

1) Hydroxide scrubber. Upfront is the molten hydroxide scrubber, which is envisioned as a slowflowing waterfall of a molten hydroxide mixture with low $T_{\mathrm{m}}$ over a stationary high-surface-area substrate (e.g., a packed bed of nickel spheres). The substrate should be able to remove particles and salt residue from the gas stream and act as a "non-pluggable" filter. It should also dissolve and trap alkaline species (e.g., Cs, Ba, Rb, Sr, La), noble metals (e.g., Ru, Tc, Se, Te), halogens (i.e., $\mathrm{F}_{2}, \mathrm{Cl}_{2}, \mathrm{Br}_{2}, \mathrm{I}_{2}$ ), and acidic species (e.g., $\mathrm{CO}_{2}, \mathrm{SO}_{2}, \mathrm{SeO}_{2}, \mathrm{TeO}_{2}, \mathrm{HF}, \mathrm{HCl}$ ). Some water may be partially retained as molten hydrates, but eventually it will escape from the hydroxide scrubber. Permanent gases such $\mathrm{O}_{2}, \mathrm{Ar}, \mathrm{He}, \mathrm{Kr}$, and Xe will bypass the trap.

2) Trap for long-lived halides. Highly efficient removal of key long-lived isotopes such as ${ }^{36} \mathrm{Cl}$ and ${ }^{129}$ I may require a secondary trap made of $\mathrm{AgZ}$ or silver-impregnated aerogels.

3) Tritium trapping. Tritium is expected to be released from the hydroxide scrubber as water that can be trapped using molecular sieves or other suitable material(s), and the remaining ${ }^{3} \mathrm{H}$ will stay in the hydroxide solution as ${ }^{3} \mathrm{HO}^{-}$.

4) Oxygen gas trap. Oxygen gas (i.e., $\mathrm{O}_{2}$ ), which should be present at parts per million levels, may be removed using a titanium sponge, as was done for the MSRE off-gas, or other suitable material.

5) Noble gases. The short-lived isotopes of $\mathrm{Kr}$ and $\mathrm{Xe}$ can be allowed to decay using commercially available activated charcoal delay bed systems similar to the ones used in commercial nuclear power plants; ${ }^{85} \mathrm{Kr}$ and stable species of $\mathrm{Xe}, \mathrm{Kr}$, and $\mathrm{Ar}$ will eventually emerge from these delay beds with the He carrier. ${ }^{19 ; 20} \mathrm{The}{ }^{85} \mathrm{Kr}$, Xe, and Ar can be separated from the helium carrier using standard industrial techniques (e.g., pressure swing adsorption, cryogenic distillation). ${ }^{21}$ Depending on the applicable regulations, ${ }^{85} \mathrm{Kr}$ may be releasable, or it may need to be contained for long-term decay-in-storage. A concentrated stream of ${ }^{85} \mathrm{Kr}$ and the Xe may have commercial application; otherwise, they can be released to the ambient air. ${ }^{22}$

6) Recycle. The purified helium stream can be reinjected into the reactor system.

A drier would need to be applied to remove any water vapor (including tritium oxide) from these processes (e.g., aqueous-based processes, reactants potentially containing water) to maintain the downstream performance of the salt product for recycling. 


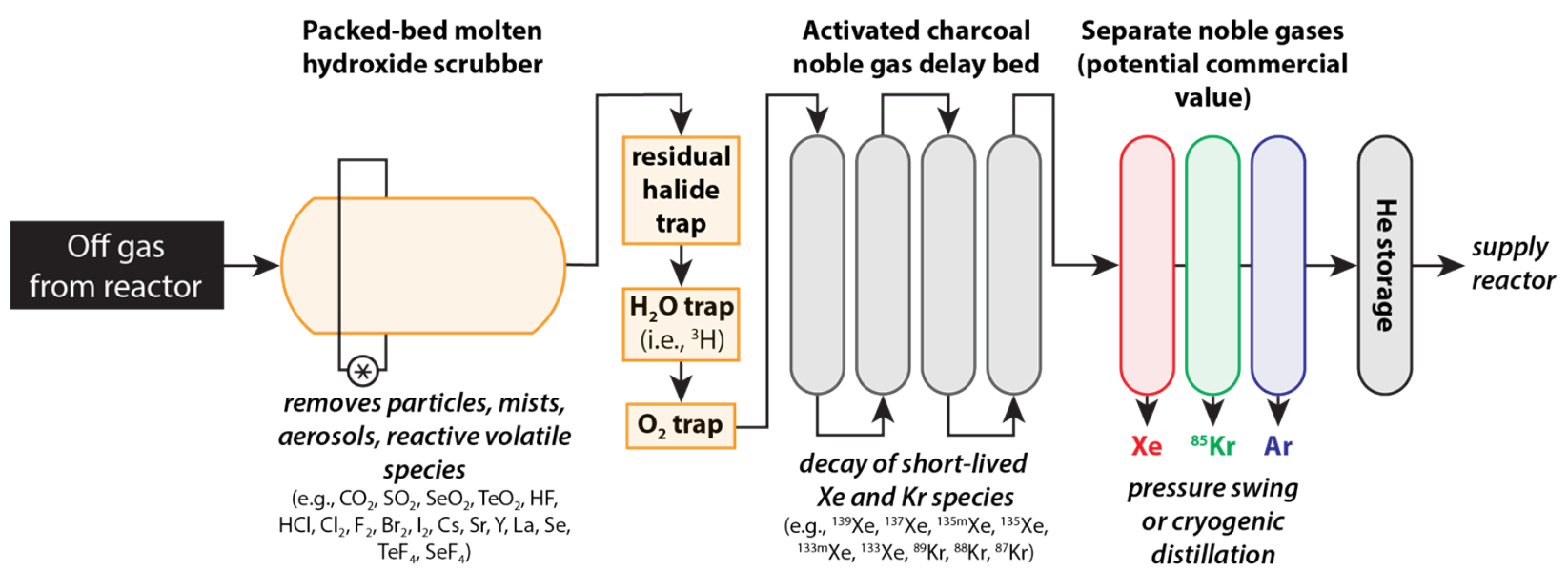

Figure 2. Schematic of the overall off-gas system for a commercial MSR based on the MSRE experience. All of the components shown, except the molten hydroxide packed-bed scrubber, are commercially available.

The advantage of the molten hydroxide scrubbing for the 90-day holdup period proposed for MSBR is that it would efficiently remove both salt mists and acidic gases, simplifying handling of the noble gas fission products.

\subsection{Detection and monitoring of fission and activation products (including tritium), sensor systems}

Online detection of fission and activation products can enable enhanced understanding and optimization of off-gas treatment systems. Multiple detection techniques can be deployed for off-gas characterization, and a combination of techniques can provide a comprehensive analysis of system components.

Deployable technologies include radiation-monitoring devices, as well as other detection techniques such as optical spectroscopy.

Optical spectroscopy can be a key detection component for several fission and activation products of interest. This technique can provide characterization of chemical species, composition ratios, and concentrations. Detectable species not only include iodine compounds such as those characterized under this phase of project work, but also include several other key species such as tritium. Raman spectroscopy is a vibrational technique and is therefore limited to the analysis of polyatomic species. Several analytes of interest to this project are in this category and are known to be Raman active. Furthermore, a Raman detector with sufficient resolution can separate response peaks of species such as $\mathrm{H}_{2}, \mathrm{HT}$, and $\mathrm{T}_{2}$ whose frequency positions are 4,160,3,434, and 2,463 $\mathrm{cm}^{-1}$, respectively. ${ }^{23,24}$ The relative Raman cross section (sensitivity) for $\mathrm{H}_{2}$ compared to diatomic nitrogen $\left(\mathrm{N}_{2}\right)$ is $2.2,{ }^{25,26}$ indicating the utility of the Raman technique. This technique can be used to identify the presence, quantity, and ratios of gaseous molecular species present.

For example, Raman spectroscopy can be leveraged to identify and quantify tritium in polyatomic forms, such as $\mathrm{T}_{2}$ and $\mathrm{TF}$, to be differentiated from $\mathrm{H}_{2}$ and HF. ${ }^{24,27}$ While not studied under fiscal year (FY) 2019 work scope, expansion of the Raman online monitoring technique to tritium can be explored under a future work scope. 


\section{FY 2019 EXPERIMENTAL PROGRAM}

The objective of the FY 2019 off-gas project was to test optical methods of detecting fission product and aerosol or mist species that could be entrained in the off-gas flow of an MSR and to test a lab-scale prototypical molten hydroxide scrubber for the removal of aerosol simulants.

The project has progressed along two fronts: the first focused on scrubber development at Oak Ridge National Laboratory (ORNL) and the second one focused on spectroscopic detection of simulant fission product iodine at Pacific Northwest National Laboratory (PNNL).

The scrubber development is proceeding in two stages, the first of which is documented in this report. The prototype scrubber was constructed of glass to allow visualization of the pumped loop and the collection of particulates in the bottom of the vessel. An inert fluid with similar flow properties to molten $\mathrm{NaOH}$ will be used to test pump operation (or water). A pump sized for $7 \mathrm{~L} \mathrm{~min} .^{-1}$ will circulate fluid over a Raschig-ring packed bed to provide an enhanced surface area for contact with the incoming gas. Aerosol generation to test the scrubber operation will be completed by passing argon or nitrogen through a fluidized bed. The glass scrubber will be replaced with a similarly sized stainless steel unit for a molten $\mathrm{NaOH}-\mathrm{KOH}$ eutectic. The scrubber will be operated at about $200^{\circ} \mathrm{C}$. Fluoroelastomer (Teflon or PTFE) components and compression fittings were used in the scrubber design.

The setup will first be used with the laser-induced ablation spectroscopy (LIBS)/laser-induced fluorescence (LIF) detection system available at ORNL (Figure 3). However, the apparatus will be configured to allow easy replacement of the LIBS/LIF with a Raman optical setup provided by (or specified by) PNNL. The LIBS/LIF method is applicable to both volatile species and aerosols, and the performance of the scrubber will be tested using this method. The Raman method developed by PNNL will target iodine species and HF as mentioned earlier. Samples will be taken from the hydroxide salt for off-line analysis at PNNL.

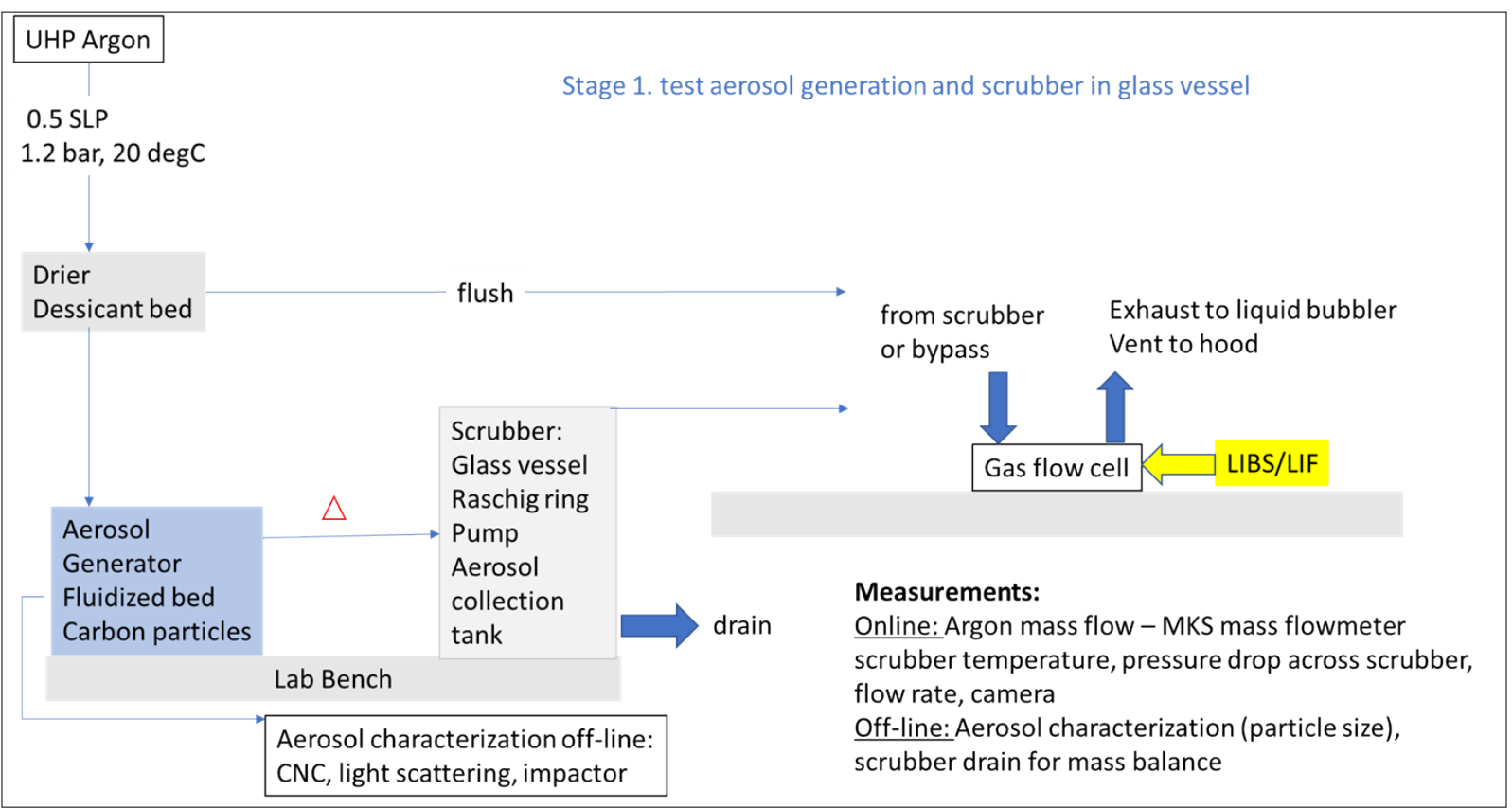

Figure 3. Schematic of lab setup for testing of glass prototype scrubber.

In the latter stages of FY 2019 and into FY 2020, the glass scrubber will be replaced with a stainless-steel unit with actual molten hydroxide material as shown in Figure 4. This unit will be tested with generated simulant fission product vapors and salt particulates or mists to ascertain the removal efficiency of the 
scrubber. The scrubber will serve as a test bed for sensors and mechanical performance, as well as chemical species detection.

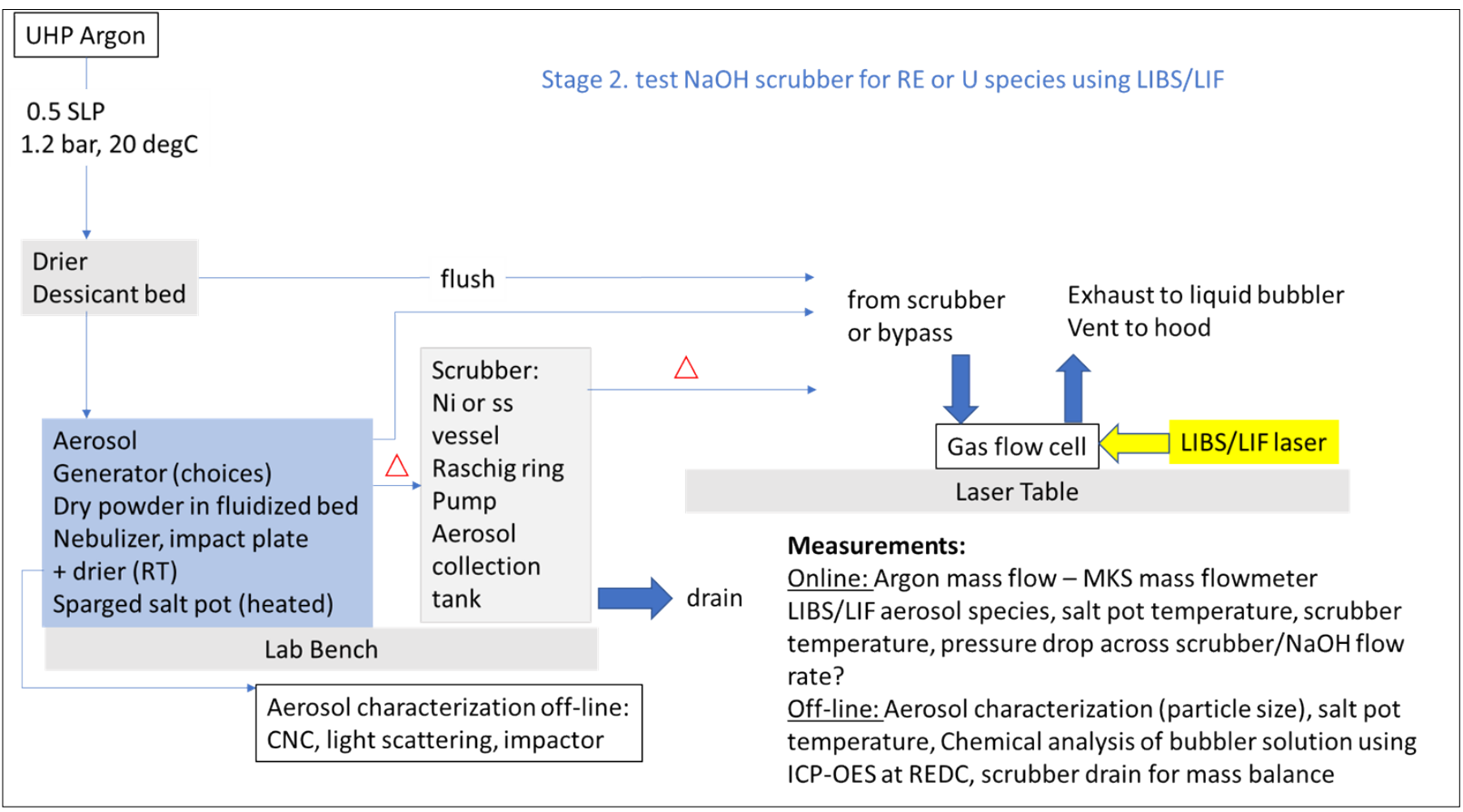

Figure 4. Schematic of lab setup for testing of molten hydroxide scrubber.

\subsection{Spectroscopic measurements}

The LIBS/LIF analysis is ORNL's contribution to the other half of the off-gas program in FY 2019, namely development of the spectroscopic detection of fission products. PNNL is developing a Raman method for detection of iodine species in the vapor phase. The PNNL team has demonstrated the sensitivity of the technique using an excitation wavelength of $670 \mathrm{~nm}$, which is off-resonance from the absorption of $I_{2}$. They will also quantify sensitivity at $532 \mathrm{~nm}$, which is on-resonance and therefore expected to be more sensitive. The advantage of several excitation wavelengths is that it will allow simultaneous detection of a variety of iodine species. PNNL is also developing an analysis tool based on a chemometric approach that will permit identification and quantitation of each analyte of interest.

\subsubsection{Raman}

Optical spectroscopy is an ideal tool for characterizing the chemical constituents of a given sample or process stream. This approach typically relies on mature and robust technology, and significant information regarding chemical composition, concentration, oxidation state, and more can be quickly obtained via online probes. More importantly, interrogating samples or a stream with multiple forms of spectroscopy can provide a comprehensive analysis of the chemical system. When characterizing gas streams, Raman spectroscopy is a powerful tool for identifying and quantifying polyatomic species. It can provide fast ( $<1$ second) measurements using robust probes that can be easily incorporated into gas lines. Over the course of FY 2019 work, PNNL demonstrated the utility of this technique to the detection and quantification of $\mathrm{I}_{2}$ and $\mathrm{ICl}$ within the gas phase.

The FY 2019 scope first focused on designing a gas phase measurement system. Figure 5 depicts the schematics and pictures of the system. The gas measurement cell was designed with quartz windows procured from the Kurt J. Lesker Company, and the Raman probes were positioned to interrogate the gas loaded into the cell. The measurement cell was connected to a vacuum line to allow for cleaning the full 
cell and selectively introducing only the target analyte to the measurement cell. The cell was connected to an MKS baratron gauge capable of measuring between 10 and 13,000 $\mathrm{Pa}$ with an uncertainty of $1 \mathrm{~Pa}$. Leak tests indicated that less than $10 \mathrm{~Pa}$ of measurable pressure leaked into the measurement cell during 5 minutes. Heat tape and J-Kem temperature controllers were used to set, control, and maintain the temperature within the sample and measurement systems. Two Raman systems from Spectra Solutions were tested, and both systems utilized similar detection systems: Spectra Solutions Inc. fiber-optic spectrometer equipped with a solid-state (DPSS) lasers and a high-throughput volume phase holographic grating Raman spectrograph. A custom transmission volume phase holographic grating spectrograph with a thermoelectrically cooled charge coupled detector was used to record the Raman signal. Two laser wavelengths were used: $671 \mathrm{~nm}$ and $532 \mathrm{~nm}$. Detectors/probes were fitted with appropriate filters and gratings to accommodate the excitation wavelength.

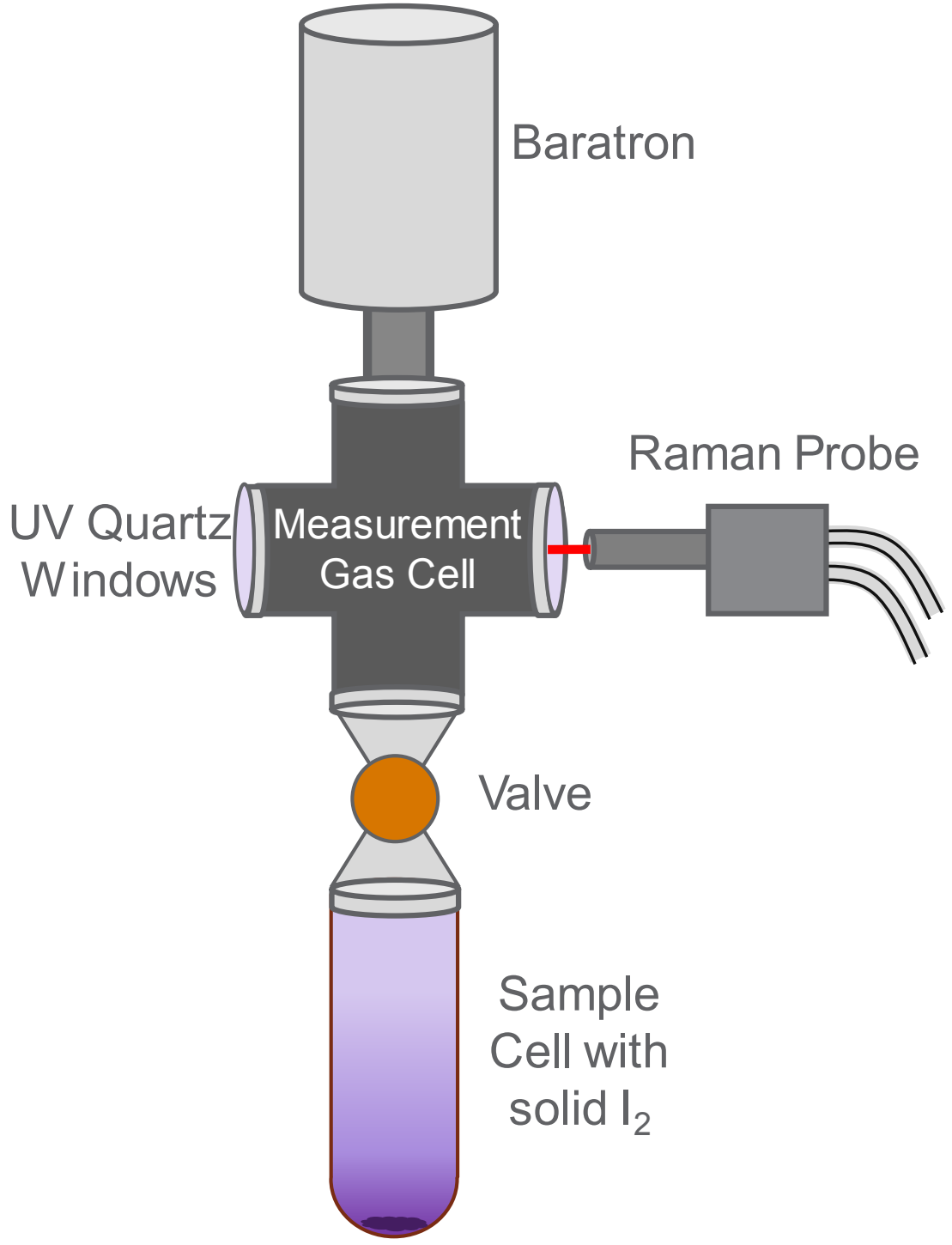

Figure 5. Schematic of the Raman signature collection system.

Two separate Raman system were used to characterize the signatures of $\mathrm{I}_{2}$ and $\mathrm{ICl}$ to determine what system parameters would provide the best detection systems. The 671 and $532 \mathrm{~nm}$ laser systems provide different excitations and therefore interrogate the system slightly differently. Generally, lower wavelength systems provide higher signals (and lower limits of detection), but higher wavelength systems are less 
likely to suffer from increased fluorescence backgrounds. In the case of $\mathrm{I}_{2}$, other variations are observed. Both the 532 and $671 \mathrm{~nm}$ excitation systems initiate fluorescence and Raman response, though fluorescence signatures are slightly different between the two excitation lasers. Figure 6 presents the spectral signatures observed when using the two Raman systems to interrogate gaseous $I_{2}$. Note, the signatures observed for the $671 \mathrm{~nm}$ system showed the presence of multiple fingerprints, likely originating from the presence of different species of $\mathrm{I}_{2}$, including gaseous species and species that had plated to the quartz window of the sample cell. Although this can complicate analysis of the data, this can provide valuable insight into the behavior of $\mathrm{I}_{2}$ and alternate routes to characterizing this target analyte within the system.

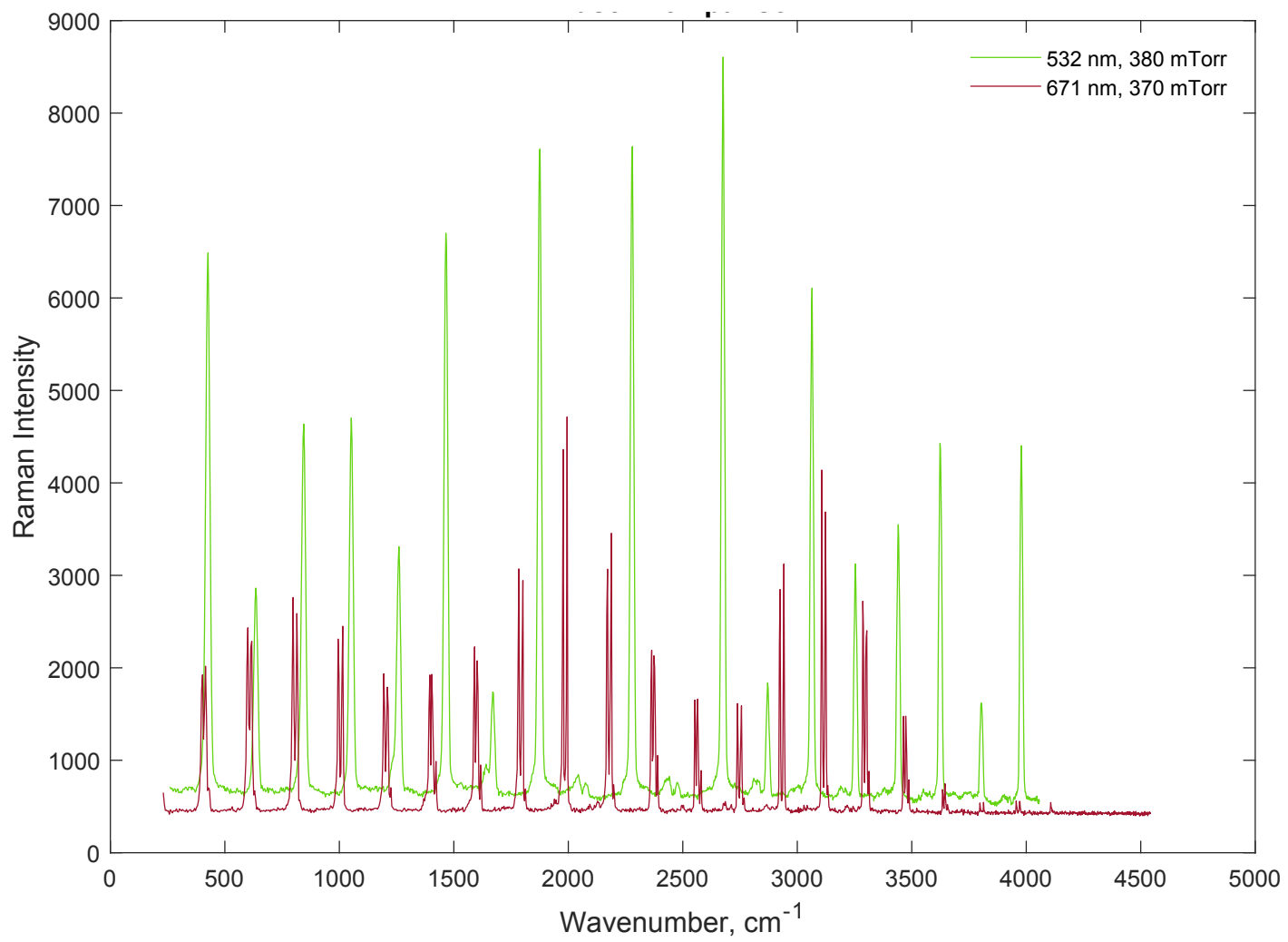

Figure 6. Spectral signatures observed for the $\mathrm{I}_{2}$ systems using both the 671 and $532 \mathrm{~nm}$ Raman systems. The spectral traces are red and green respectively, according to the excitation wavelength, with the lower -intensity green trace offset in the positive y-direction from the red.

In addition to identifying the signatures of the gaseous species, FY 2019 goals included building initial calibration curves for the target analytes. Raman signal intensity changes with partial pressure of target analyte; however, to simplify data analysis and signature collection, a vacuum system was used, and the target analyte was the only gaseous species introduced to the sample cell. Total pressure was measured by a Baratron gauge, and the total sample pressure was increased by opening the valve between the sample cell and the measurement cell. Spectral signatures from discrete pressure steps can be seen in Figure 7. 

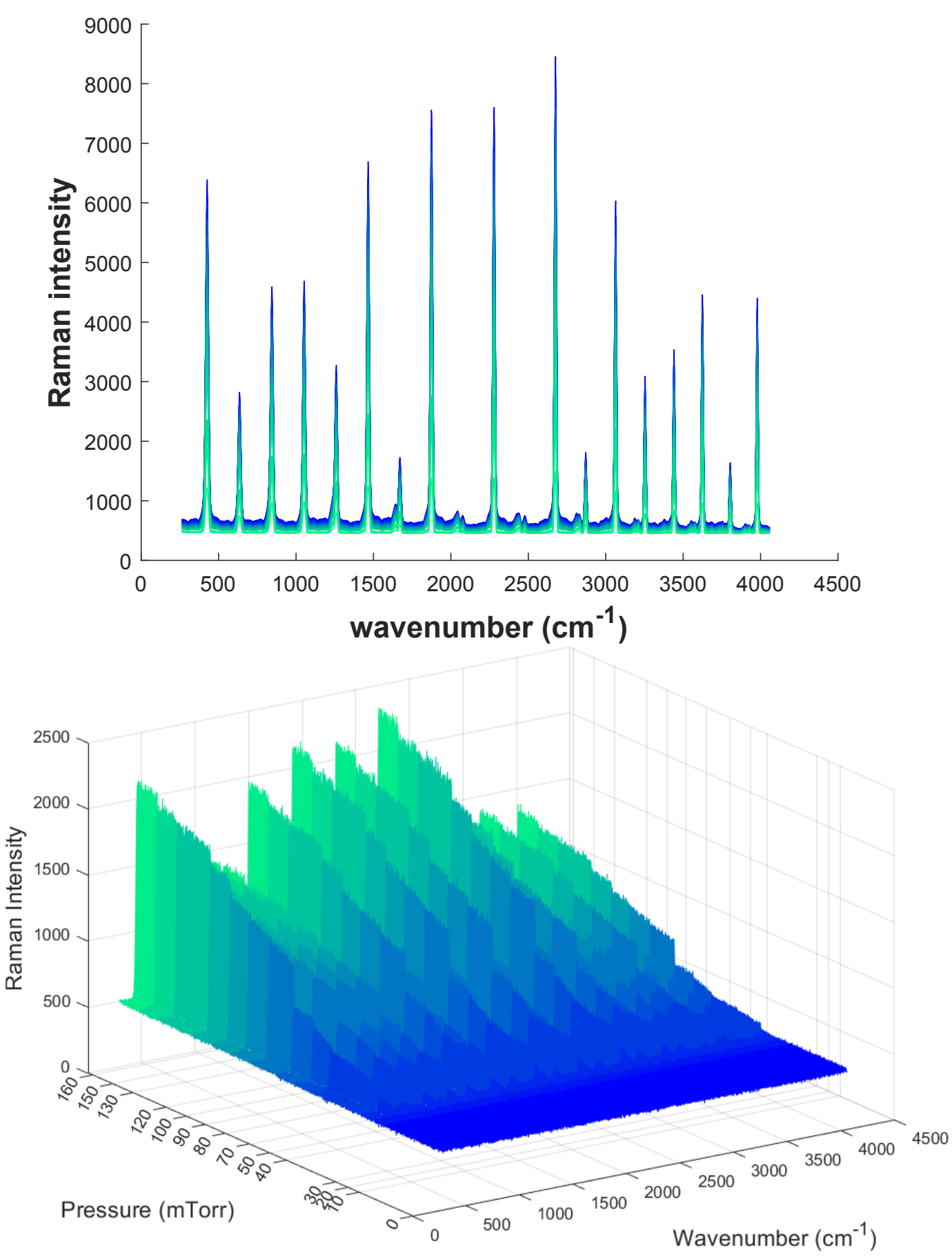

Figure 7. Spectral signatures observed for $\mathrm{I}_{2}$ at $25^{\circ} \mathrm{C}$ while stepping pressure from 0 to $33 \mathrm{~Pa}$ using the $532 \mathrm{~nm}$ laser system. The upper frame is a normalized superposition of the spectra that have been split out in the lower frame.

Raman signatures can also potentially vary with the system temperature. To capture Raman signatures, pressure variation experiments were completed at 25, 50, and $100 \mathrm{mTorr}$ (3-13 Pa) for both the 532 and $671 \mathrm{~nm}$ laser systems. For the $532 \mathrm{~nm}$ system, the signature remains roughly constant for all temperatures studied. The $671 \mathrm{~nm}$ system shows slightly different behavior as a function of temperature, likely because 
of different speciation and plating kinetics at elevated temperatures. Figure 8 presents superimposed spectra with two different signatures that were identified using the $671 \mathrm{~nm}$ laser system. Future work may leverage advanced data analysis techniques to determine if these varying signatures can be related back to system parameter-dependent behavior, which would expand our understanding and capabilities to monitor and control $\mathrm{I}_{2}$ off-gas.

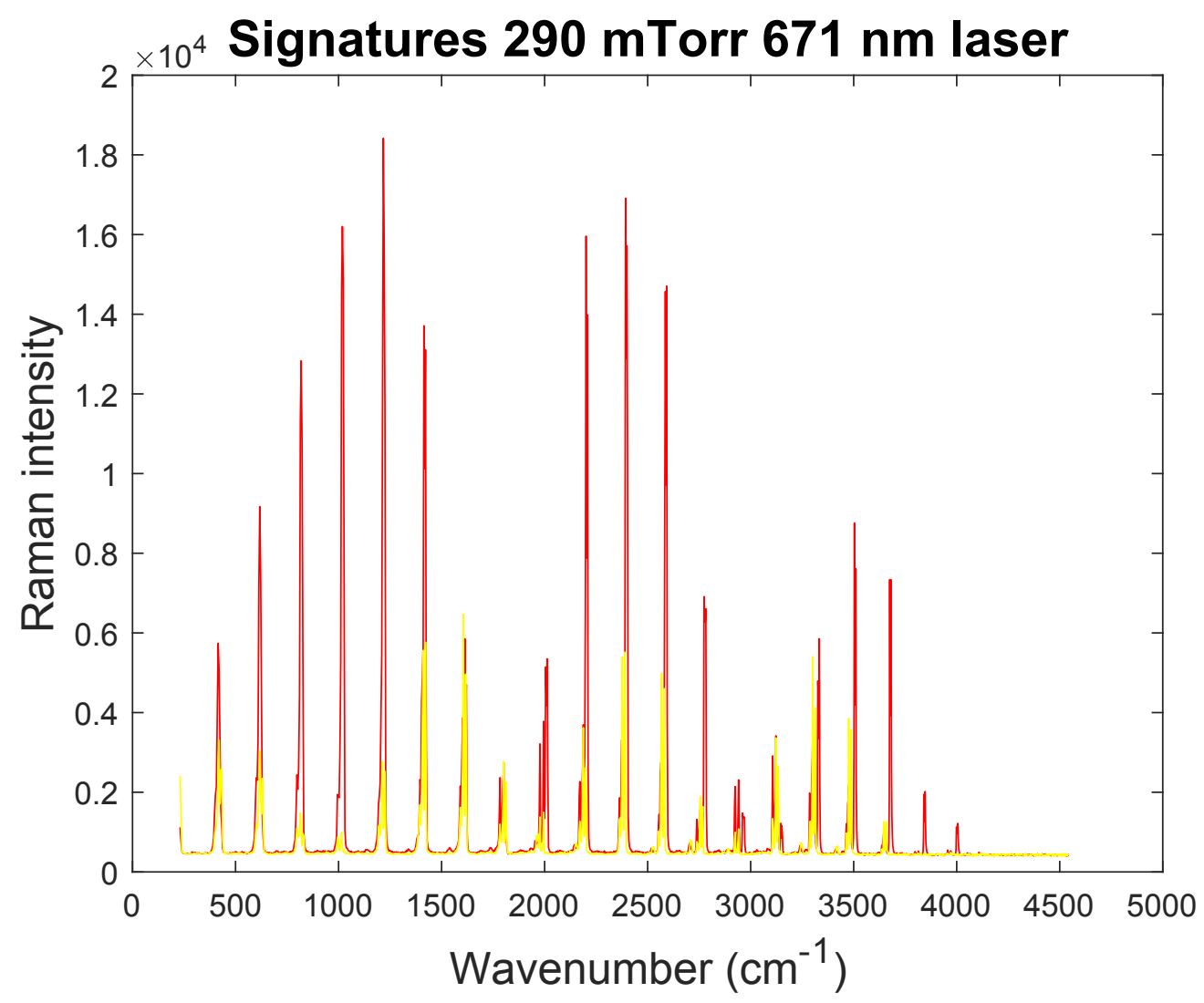

Figure 8. Spectral signatures observed for $\mathrm{I}_{2}$ using the $671 \mathrm{~nm}$ laser system. Two unique spectral fingerprints were identified, which indicates two separate species of $\mathrm{I}_{2}$ are present within the gas system.

Raman signatures were also collected for ICl while varying pressure and temperature. Examples of ICl Raman spectra are shown in Figure 9. Comparisons of $\mathrm{I}_{2}$ and ICl signatures yield notably different Raman and fluorescence bands. However, $\mathrm{ICl}$ also has distinguishable infrared bands. These signatures will be discussed below and represent another avenue for selectively identifying and potentially quantifying target analytes. 

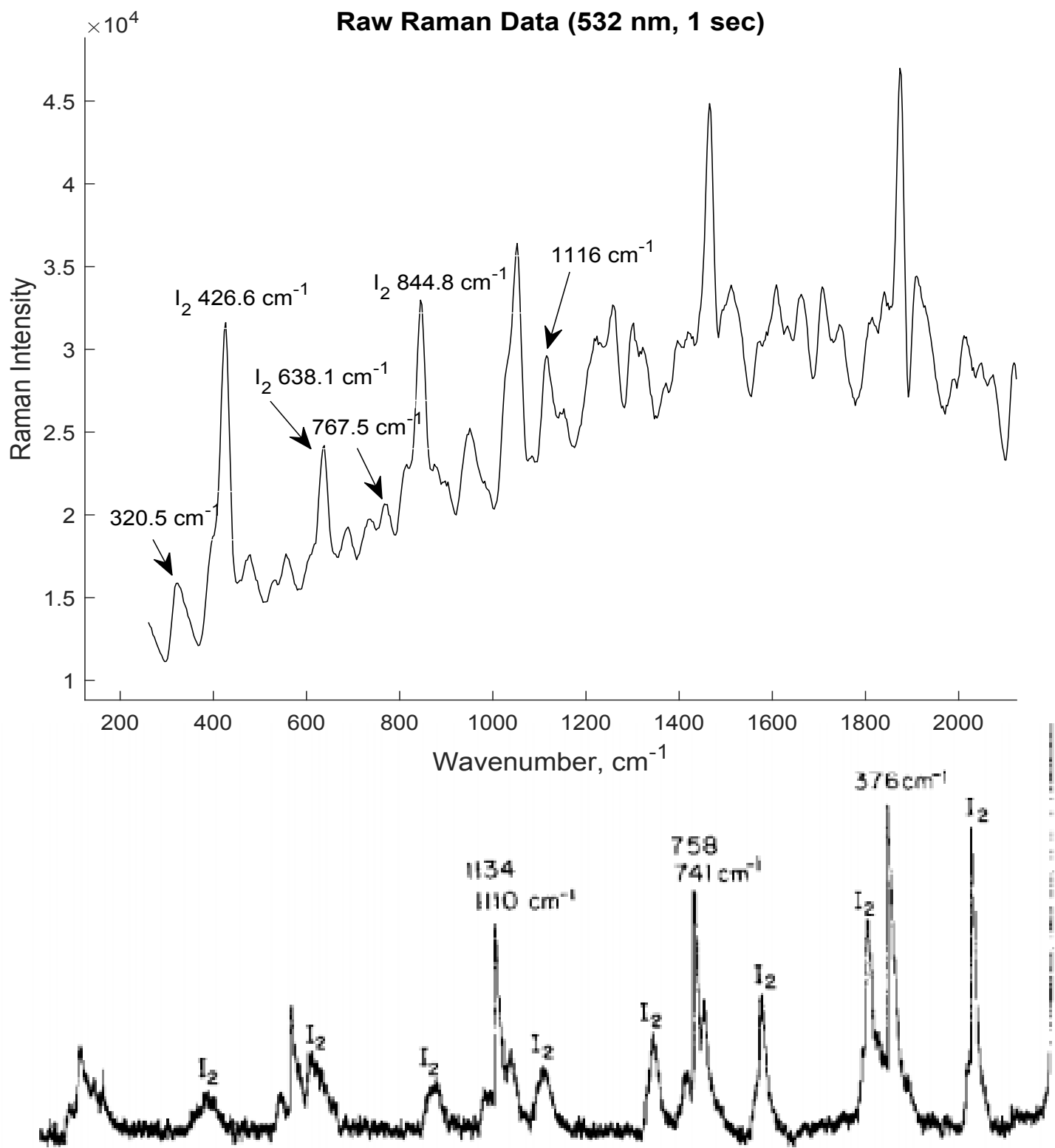

Fig. 6. The resonance Raman spectrum of $\mathrm{ICl}$ gas. The bands arising from $\mathrm{I}_{2}$ are indicated. The isotope structure due to chlorine is apparent in the overtones. ICl, 20 torr; slits, $7.5 \mathrm{~cm}^{-1}$; time constant, $2 \mathrm{sec} ; 11.5 \AA / \mathrm{min} ; 4880$ - $\AA$ excitation.

Figure 9. Signatures of ICl obtained using the $532 \mathrm{~nm}$ Raman system (top) with a comparison to literature values from Holzer et al. (1970) (bottom). Reproduced with permission from J. Chem. Phys. 52, 399

(1970). Copyright 1970, American Institute of Physics.

Collected spectral signatures were used to build traditional calibration curves, following maximum signal intensity as a function of analyte pressure within the measurement cell. Separate calibration curves were built for each temperature studied. Future work will focus on building advanced data analysis algorithms and chemometric models to quantify target species. However, the initial analysis using traditional 
calibration curves generally indicated future modeling can be successfully applied. Figure 10 includes examples of calibration curves for $\mathrm{I}_{2}$. In the case of the $671 \mathrm{~nm}$ system with multiple observed signatures (correlating to the identification of multiple species), separate calibration curves are required for each species. Calibration curves for one signature/species are presented in the bottom plot of Figure 8 , and the limits of detection are listed in Table 2. This system represents a direct example of how chemometric modeling may provide faster and more accurate system analysis than traditional calibration curves. Additionally, the $\mathrm{I}_{2}$ signature observed when using the $532 \mathrm{~nm}$ system primarily includes the fluorescence bands of the species. This has some major benefits, including low limits of detection for $\mathrm{I}_{2}$ due to the strong fluorescence signal. However, the fluorescence bands are known to show quenching behavior at higher pressures. This quenching behavior is observed in our system; the signal begins to show nonlinear behavior above $13 \mathrm{~Pa}$. The calibration curves presented in Figure 10 are limited to the linear response range. At higher pressures, the primary Raman band may be the best option for following $\mathrm{I}_{2}$ presence in the gas stream. The current detector setup is not capturing the primary Raman response band, which occurs below the cutoff for the grating. However, a corrected spectrograph will be provided by Spectra Solutions, which has a grating cutoff set low enough to capture the Raman band. This system will be used to capture the full $\mathrm{I}_{2}$ fingerprint. Limits of detection (LOD) were calculated using the equation:

$$
L O D=\frac{3 s_{b}}{m},
$$

where $s_{b}$ is the standard deviation of the noise, and $m$ is the slope of the calibration curve (see Figure 10). It should be noted that for the data collected with the $532 \mathrm{~nm}$ laser (top plot of Figure 10) the results are grouped between the low temperature data $\left(25^{\circ} \mathrm{C}\right.$ and $\left.50^{\circ} \mathrm{C}\right)$ and the high temperature data $\left(75^{\circ} \mathrm{C}\right.$ and $100^{\circ} \mathrm{C}$ ). Looking at calculated limits of detection (Table 2) confirms the low and high temperature groupings. For the $671 \mathrm{~nm}$ system, responses across the temperature range show a more consistent variation of response with temperature, and the differences in limits of detection again correspond with observed calibration curves. 
Table 2. Limits of detection for target analytes

\begin{tabular}{|c|c|c|c|}
\hline $\begin{array}{l}\text { Temperature } \\
\left({ }^{\circ} \mathrm{C}\right)\end{array}$ & $\begin{array}{l}\text { LOD } \\
\text { (mTorr } \\
\text { /Pa) }\end{array}$ & Band type & Notes \\
\hline \multicolumn{4}{|c|}{$\mathrm{I}_{2}$ response curves } \\
\hline 25 & $\begin{array}{l}1.29 \\
/ 0.17\end{array}$ & $\begin{array}{l}532 \mathrm{~nm} \text { excitation, } \\
\text { fluorescence }\end{array}$ & $\begin{array}{l}\text { All } 532 \mathrm{~nm} \text { excitation data will be limited to } \\
\text { approximately } 100 \mathrm{mT} \text { orr }(13 \mathrm{~Pa}) \text {, above which, } \\
\text { lower wavenumber Raman response bands will need } \\
\text { to be used }\end{array}$ \\
\hline 50 & $\begin{array}{l}1.77 \\
/ 0.24\end{array}$ & $\begin{array}{l}532 \mathrm{~nm} \text { excitation, } \\
\text { fluorescence }\end{array}$ & \\
\hline 75 & $\begin{array}{l}0.47 \\
/ 0.063\end{array}$ & $\begin{array}{l}532 \mathrm{~nm} \text { excitation, } \\
\text { fluorescence }\end{array}$ & \\
\hline 100 & $\begin{array}{l}0.52 \\
/ 0.069\end{array}$ & $\begin{array}{l}532 \mathrm{~nm} \text { excitation, } \\
\text { fluorescence }\end{array}$ & \\
\hline 20 & $\begin{array}{l}0.23 \\
/ 0.031\end{array}$ & $\begin{array}{l}671 \mathrm{~nm} \text { excitation, } \\
\text { fluorescence }\end{array}$ & $\begin{array}{l}\text { Calibration curve and LOD values focus on the most } \\
\text { predominant signature/species }\end{array}$ \\
\hline 75 & $\begin{array}{l}0.17 \\
/ 0.023\end{array}$ & $\begin{array}{l}671 \mathrm{~nm} \text { excitation, } \\
\text { fluorescence }\end{array}$ & \\
\hline 100 & $\begin{array}{l}0.13 \\
/ 0.017\end{array}$ & $\begin{array}{l}671 \mathrm{~nm} \text { excitation, } \\
\text { fluorescence }\end{array}$ & \\
\hline \multicolumn{4}{|c|}{ ICl response curves } \\
\hline 20 & $\begin{array}{l}0.28 \\
/ 0.037\end{array}$ & FTIR & $\begin{array}{l}\text { Given complexity of ICl Raman data, calibration } \\
\text { curve results indicate more advanced data processing } \\
\text { will be needed to accurately analyze spectral data. } \\
\text { FTIR data provides simpler signatures and can be } \\
\text { used to determine limits of detection }\end{array}$ \\
\hline
\end{tabular}



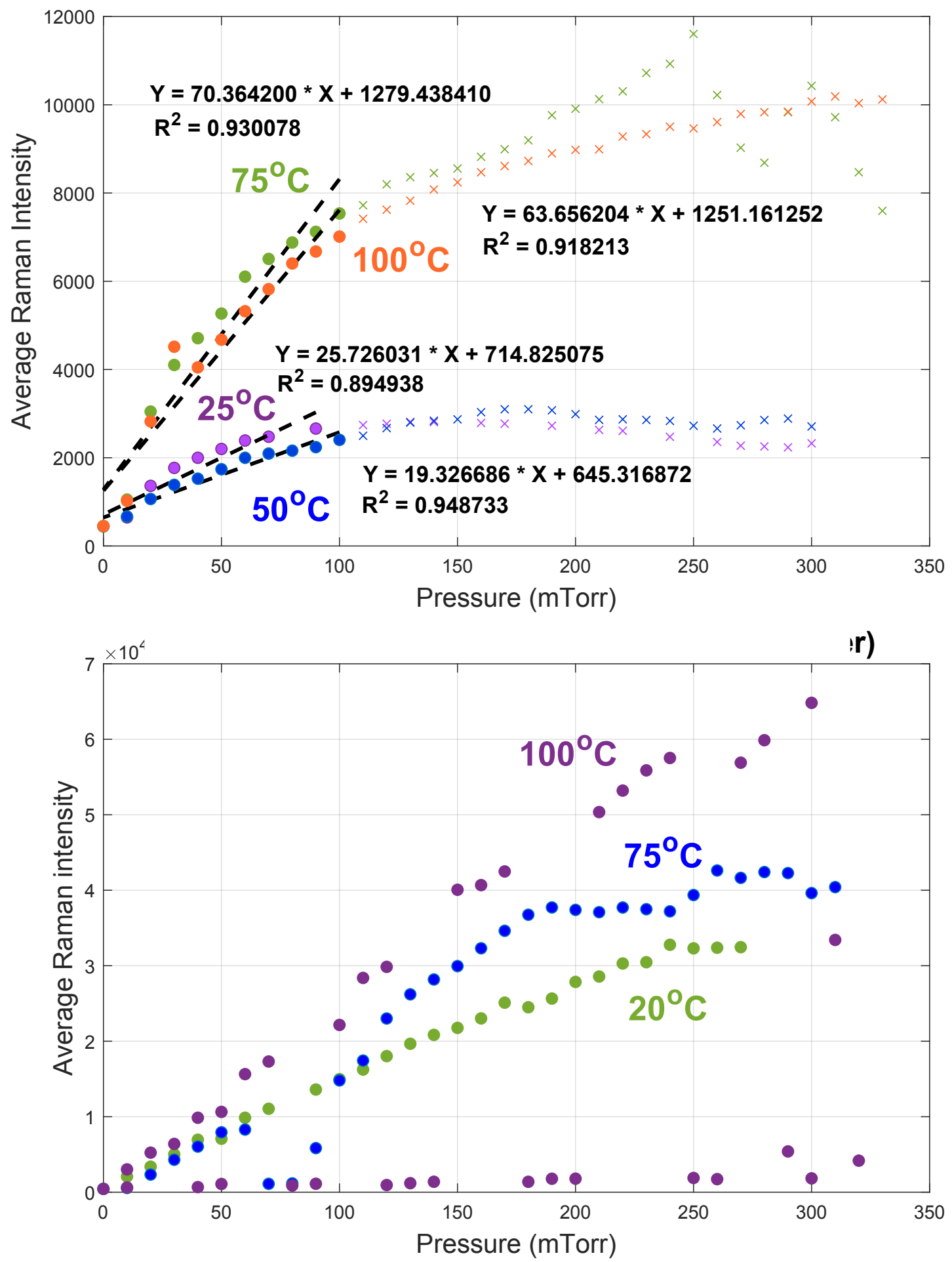

Figure 10. Calibration curves showing relationship of Raman signal intensity to $I_{2}$ pressure at multiple temperatures for the 532 (top) and $671 \mathrm{~nm}$ (bottom) laser systems. 
If limits of detection listed in Table 2 do not meet operational needs, it is possible to improve Raman capabilities. Detection limits could be improved through altering system specifications, such as increasing the interrogation path length or increasing laser power. Additionally, using advanced chemometric analysis can enable higher accuracy of results and potentially allow for increased data analysis range.

\subsubsection{LIBS/LIF}

A LIBS/LIF system for monitoring off-gas has been developed (Figure 11). The light is introduced from the top, orthogonally to the off-gas carrier gas that will transport the fission product vapors and mists through the optical chamber. Light from the plasma created by LIBS is collected through fiber-optic cables mounted at $90^{\circ}$ to both the flow of the carrier gas and the input light. LIF can also be collected offaxis in the same plane.

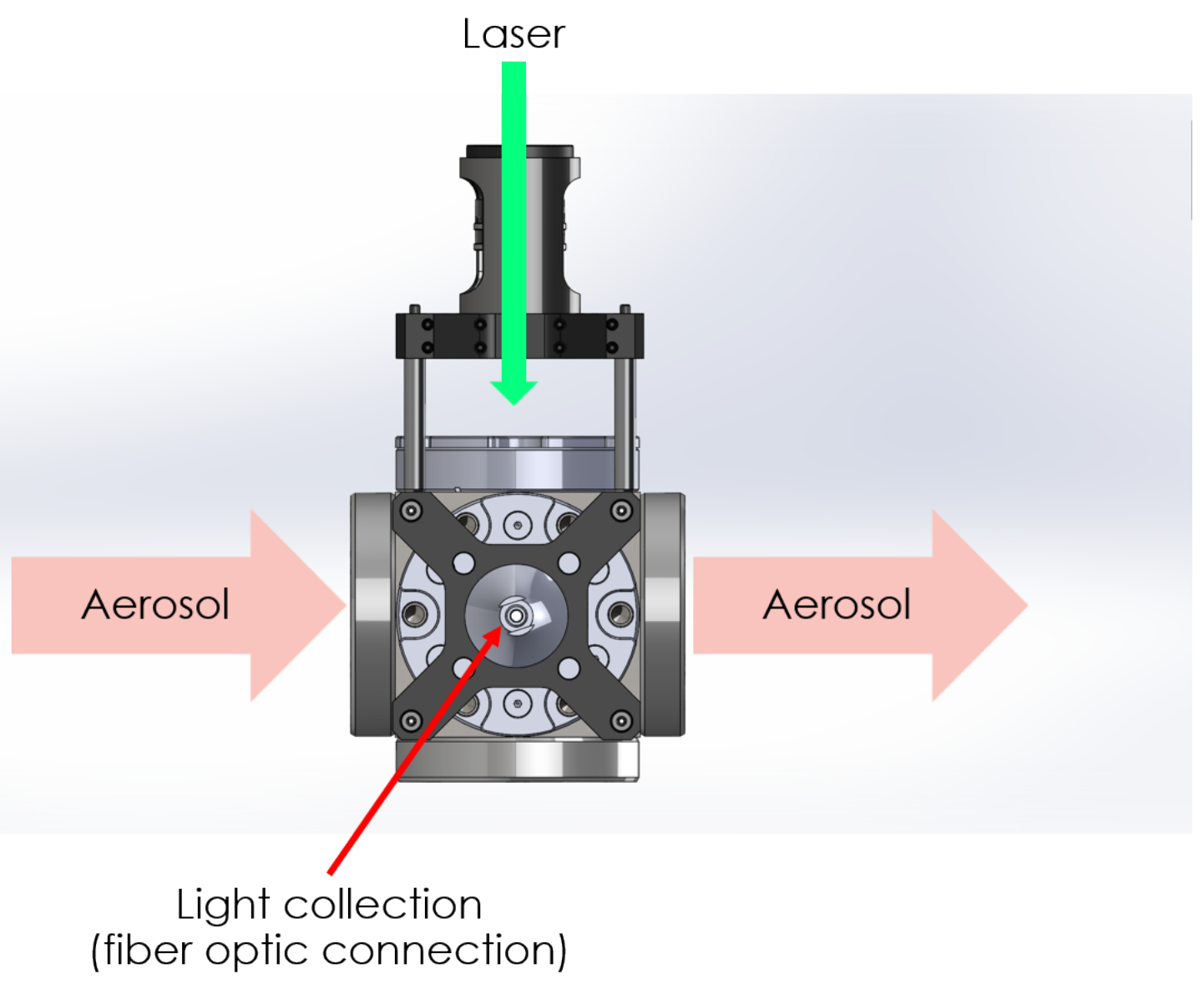

Figure 11. Optical sampling geometry for off-gas aerosol using LIBS.

The path of the carrier gas through the optical chamber is collimated by a co-axial flow of similar gas (e.g., helium or argon). This minimizes the deposition of material on the outer walls of the optical chamber and optical probes. The instrument has been tested with nebulized salt solutions, using an arrangement developed at Virginia Commonwealth University. The nebulizer is made of stainless steel and can be operated at high temperatures in a furnace, depending on the selection of vessel materials. Preliminary data show good signal-to-noise ratios for a variety of lanthanides introduced as salts into the nebulizer. However, the optical configuration is still being optimized for the geometry shown in Figure 
11. Quantitation will be achieved by measuring properties of the salt aerosol, such as particle size and concentration, using standard sampling techniques.

The LIBS apparatus is quite portable, and a housing has been developed so that scattered $1064 \mathrm{~nm}$ does not provide a risk to the staff collecting data. The LIBS will be moved to sample the output of the scrubber, which is described in Section 2.2.1. In addition, the nebulizer will be configured to operate at several hundred degrees to handle molten salts.

\subsubsection{FTIR}

The infrared absorption technique has been used for the quantitative measurement of a multitude of compounds and complexes. As with other absorption techniques, infrared (FTIR) methods also follow Beer's law and are amenable to standard quantitative methods. With the exception of mononuclear diatomic molecules (such as $\mathrm{I}_{2}$ ), all organic and inorganic compounds absorb in the infrared region of the spectrum, including ICl. The uniqueness of infrared spectra leads to high selectivity for identification and discrimination between compounds, especially with gas phase spectra, which have a high resolution (narrow band features) compared with solution phase spectra.

The spectroscopic measurement of the interhalogen iodine compounds ( $\mathrm{ICl}, \mathrm{IBr}$, and $\mathrm{BrCl}$ ) have been measured using infrared (IR) spectroscopic methods (1-4). ${ }^{28,29,30,31}$ The band center of ICl lies at $381 \mathrm{~cm}^{-1},{ }^{30,31}$ which is in the far-infrared region.

To demonstrate the ability to measure ICl in the gas phase, PNNL measured the gas-phase FTIR spectrum of $\mathrm{ICl}$ at a single pressure. Figure 12 shows a spectrum of $\mathrm{ICl}$ using a $10 \mathrm{~cm}$ path-length cell fitted with polyethylene windows. The spectrum is at $2 \mathrm{~cm}^{-1}$ resolution, which should be adequate to resolve the Pand R-branches associated with the vibrational band centered at $381 \mathrm{~cm}^{-1}$. The intensity of this vibrational band is dependent on pressure (concentration) of the gas within the path-length measured and can be used to measure the gas-phase pressure of $\mathrm{ICl}$ within the MSR off-gas system. We are currently measuring the intensity-pressure relationship of the $\mathrm{ICl}$ system using the $381 \mathrm{~cm}^{-1}$ vibrational band. 


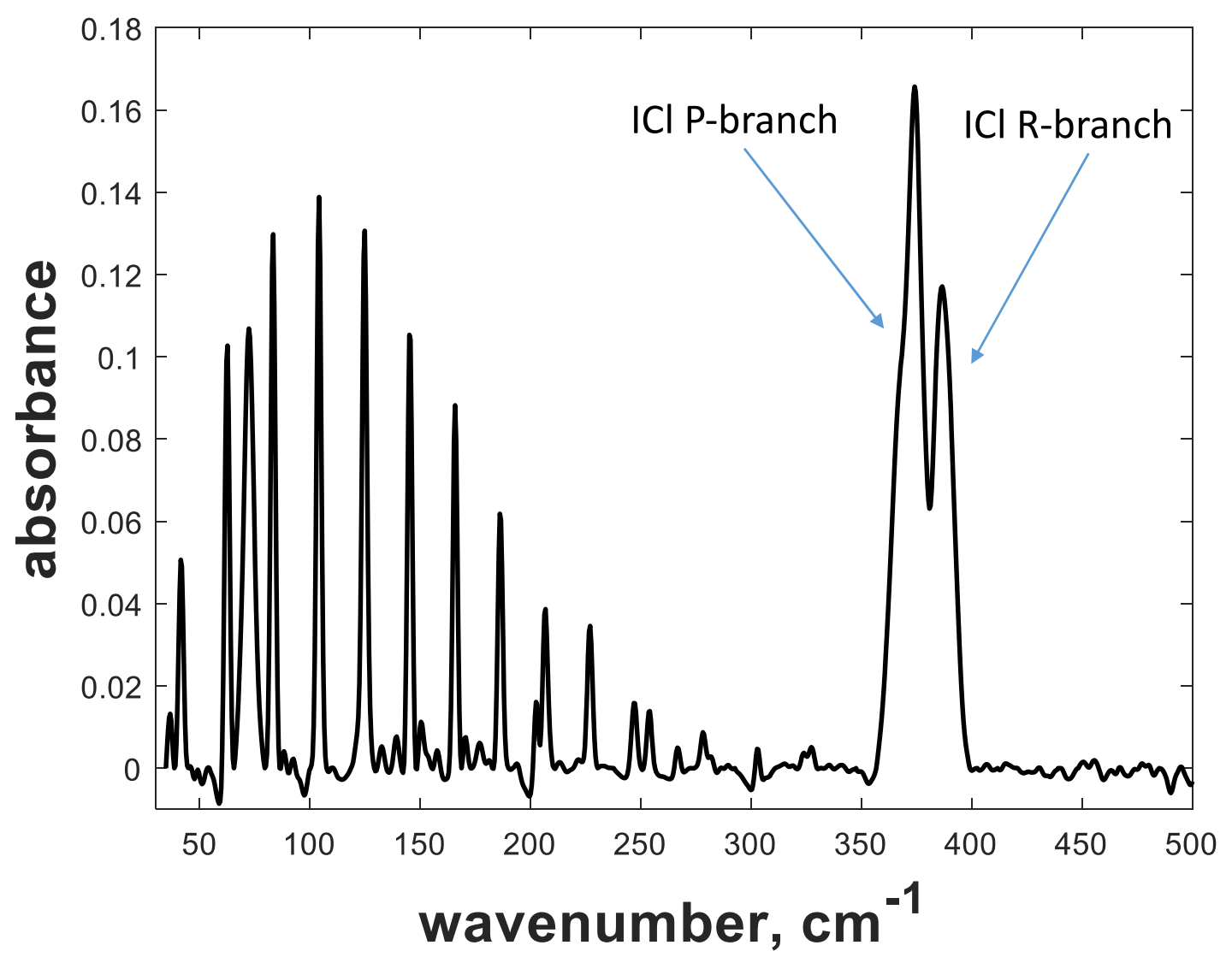

Figure 12. The infrared spectrum of ICl showing the P- and R-branch of the fundamental vibrational band. The spectrum was measured using a Bruker FTIR system at $2 \mathrm{~cm}^{-1}$ resolution.

\subsection{Molten hydroxide scrubber design}

A key part of the current off-gas investigation is the development of a proposed mixed $\mathrm{NaOH}-\mathrm{KOH}$ scrubber. Caustic scrubbers are commonly used in industry, especially for cleaning and descaling industrial equipment. ${ }^{32}$ Concentrated aqueous caustic scrubbers were used in the off-gas system for salt processing activities in the MSRE. The scrubber being developed this year will be designed to operate at $200^{\circ} \mathrm{C}$ and will effectively remove both aerosols and acidic gases. To achieve a low melting point, a eutectic mixture of $\mathrm{NaOH}-\mathrm{KOH}\left(51-49 \mathrm{~mol} \%\right.$ respectively, or $\left.41-59 \mathrm{wt} \%{ }^{33}\right)$ will be used.

Hydroxides are hygroscopic and will readily absorb $\mathrm{CO}_{2}$ from the atmosphere. Thus, measurement of thermochemical and thermophysical properties requires heating to $300^{\circ} \mathrm{C}-400^{\circ} \mathrm{C}$ under a flow of dry gas for several hours to remove most, but not all, of the residual water. The $\mathrm{CO}_{2}$ content cannot be removed and has been measured as about $2-3 \mathrm{wt} \%$ by titration with $\mathrm{HCl}$.

Takahashi reported a melting point as $444 \mathrm{~K}\left(171^{\circ} \mathrm{C}\right)$ for a $50-50 \mathrm{~mol} \%$ mixture of $\mathrm{NaOH}-\mathrm{KOH}$. Some supercooling was observed when the salt was ramped below its melting point. ${ }^{34}$ The heat capacities for this molten hydroxide eutectic measured by differential scanning calorimetry are provided in Table 3 below. The first two entries are for the solid and the third is for the molten state. The gap arises because of the phase transition around $171^{\circ} \mathrm{C}$. Note that the values are computed using temperatures in Kelvin. 
Table 3. Heat capacities of $\mathrm{NaOH}-\mathrm{KOH}$ eutectic mixture (50-50 mol\%)

\begin{tabular}{|l|l|}
\hline$C_{\mathrm{p}}\left(\mathrm{J} \mathrm{g}^{-1} \mathrm{~K}^{-1}\right)$ & Temperature Range $(\mathrm{K})$ \\
\hline $0.9047+0.001124 * T$ & $330-360 \mathrm{~K}$ (solid) \\
\hline $0.4347+0.002451^{*} T$ & $365-430 \mathrm{~K}$ (solid) \\
\hline $1.8005+0.000023^{*} T$ & $470-575 \mathrm{~K}$ (liquid) \\
\hline
\end{tabular}

Densities and electrical conductivity have been reported for purified $\mathrm{NaOH}-\mathrm{KOH}$ (51-49 mol\%) respectively. ${ }^{35}$ Densities are given in Table 4 . Molar volume, $V_{M}$, decreases, and density increases with the mole fraction of water, $X_{H 2 O}$, in the fused salt. ${ }^{36}$

$$
V_{M}=\left(\frac{(0.51 \times 40+0.49 \times 56.1)\left(1-X_{H_{2} \mathrm{O}}\right)+18 X_{\mathrm{H}_{2} \mathrm{O}}}{\rho}\right)
$$

Table 4. Densities ( $\rho)$ of $\mathrm{NaOH}-\mathrm{KOH}(51-49 \mathrm{~mol} \%)$.

\begin{tabular}{|l|l|l|l|}
\hline $\mathrm{T}\left({ }^{\circ} \mathrm{C}\right)$ & $\rho\left(\mathrm{g} / \mathrm{cm}^{3}\right)$ & $\mathrm{T}\left({ }^{\circ} \mathrm{C}\right)$ & $\rho\left(\mathrm{g} / \mathrm{cm}^{3}\right)$ \\
\hline 178 & 1.876 & 310 & 1.805 \\
\hline 192 & 1.863 & 331 & 1.801 \\
\hline 236 & 1.843 & 363 & 1.781 \\
\hline 255 & 1.834 & 400 & 1.760 \\
\hline 260 & 1.828 & 415 & 1.754 \\
\hline 290 & 1.822 & & \\
\hline
\end{tabular}

Viscosities of fused caustic salts are said to be comparable to those of water. ${ }^{37}$ Hydrated sodium salts show high viscosities close to the melting point, but these drop rapidly with temperature. ${ }^{38}$

\subsubsection{Description of glass prototype}

A prototype of the hydroxide scrubber was built to allow visualization of operation and testing of fluid flow rates before construction of a stainless-steel scrubber for the molten hydroxide system. A prototype glass scrubber was constructed and is shown in Figure 13. Figure 14 is the schematic. Gas enters through the three-way valve at the back of the unit (in the picture) and flows up through the packed bed of nickel Raschig rings. Water showers through the bed from the top, driven through the unit by a Teflon White Knight air-actuated pump, which can be seen on the right side of the photo. In preliminary testing, the pump performed as designed. Pressure is used to control the rate of flow through the unit, starting at about 1.4 bar with a flow rate of $4.5 \mathrm{~L} \cdot \mathrm{min}^{-1}$. Aerosols are expected to collect in the sump of the unit, after being directed through the Teflon cone at the entrance of the gas stream. 

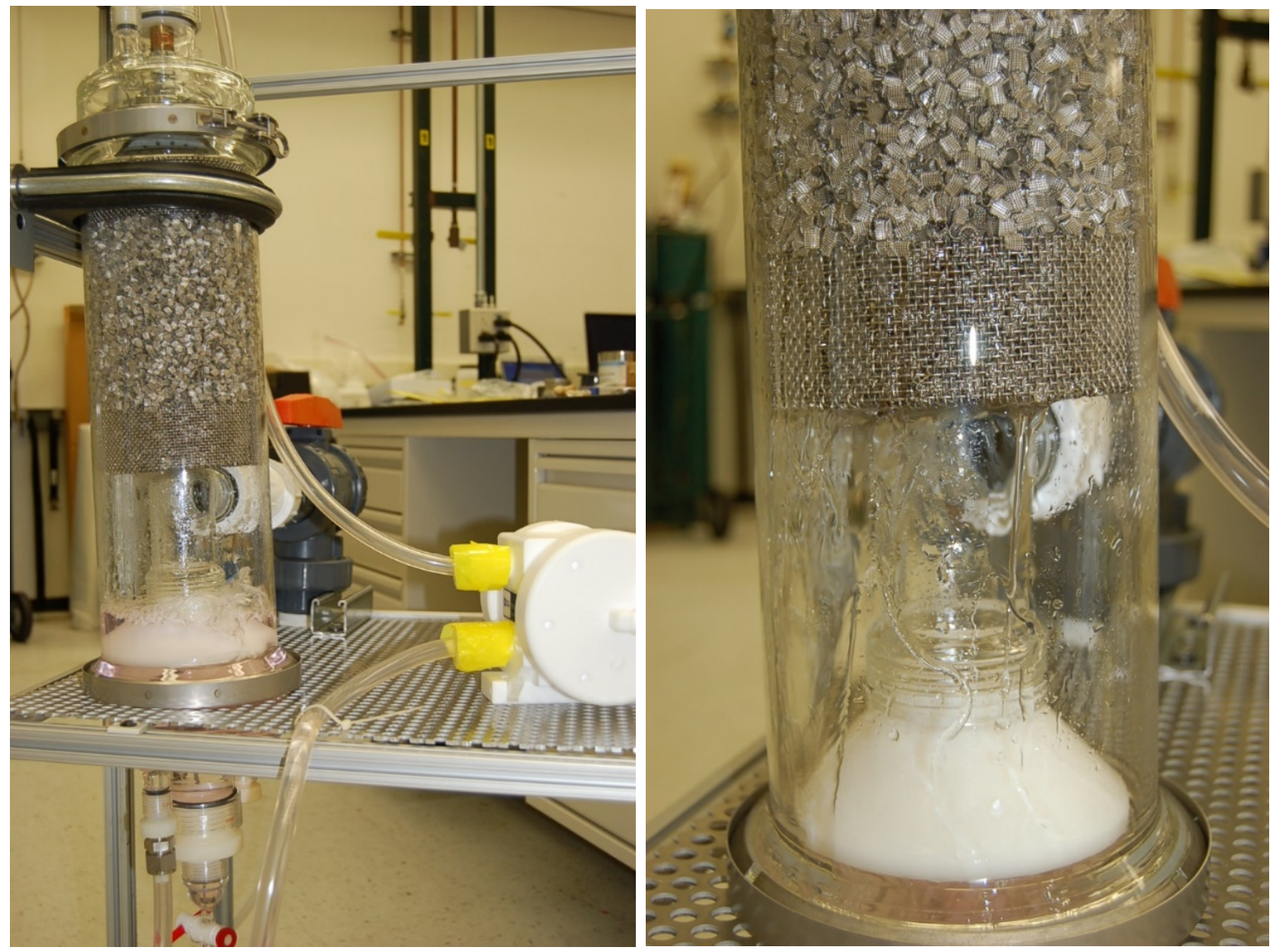

Figure 13. The molten hydroxide scrubber glass prototype showing the piston pump on the left and a higher magnification view of the fluid flow through the packed bed on the right.

A second picture was taken with the pump in operation. Water flow is apparent through the bed and into the sump. An indicator was used to impart a slight pink color to the water so that it could be better observed. 


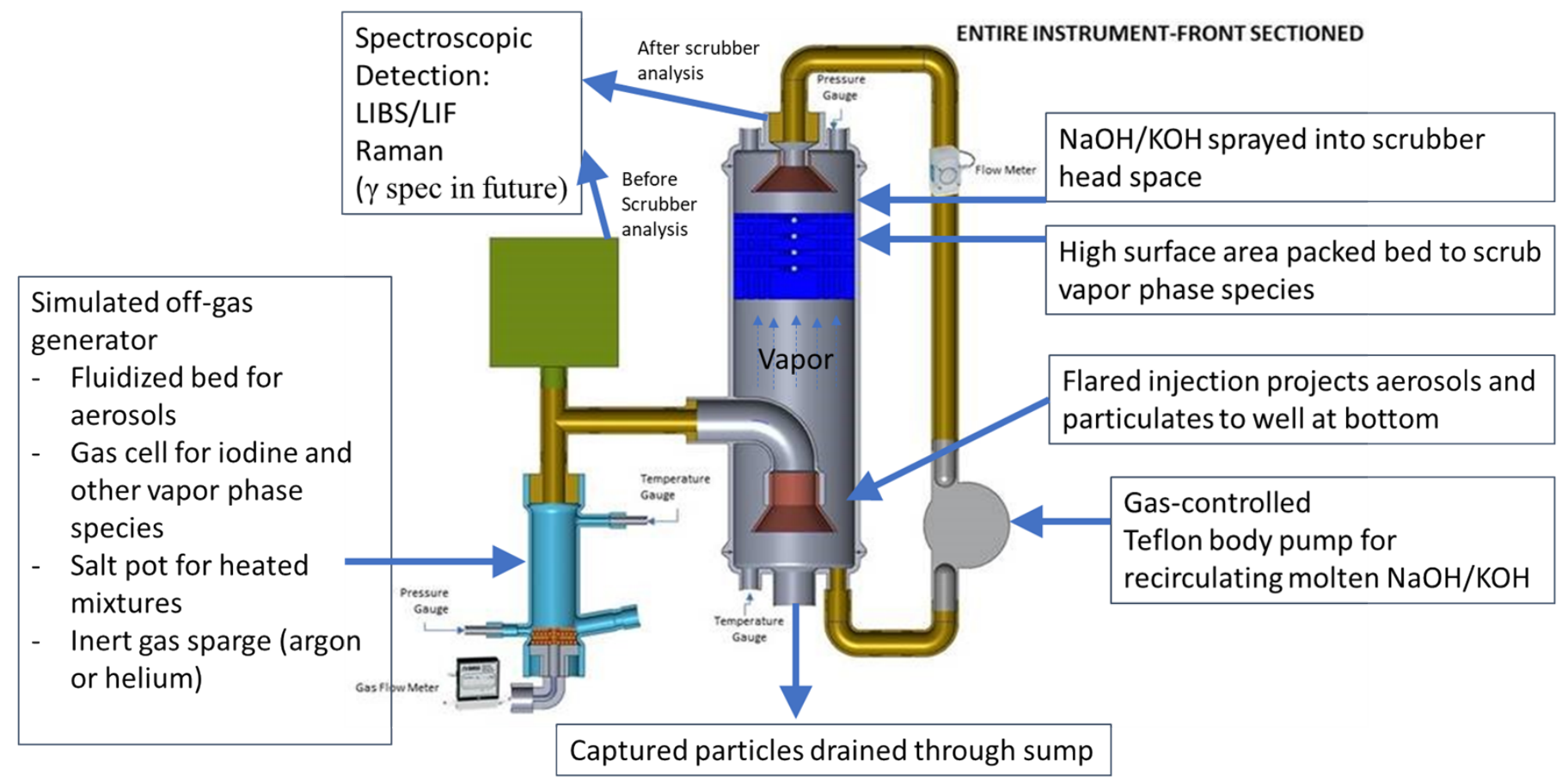

Figure 14. Schematic of glass scrubber prototype.

Introduction of simulated fission products as aerosols will be done in the summer of 2019, using a fluidized bed aerosol generator that is being manufactured. The aerosol flow will be directed through the glass scrubber and sent to a LIBS/LIF apparatus for analysis.

\subsubsection{Instrumentation and LabView programming}

To ensure the system is operating within the design parameters, several commercially available instruments were installed to monitor the temperature, pressure, and flow, see Figure 155. 


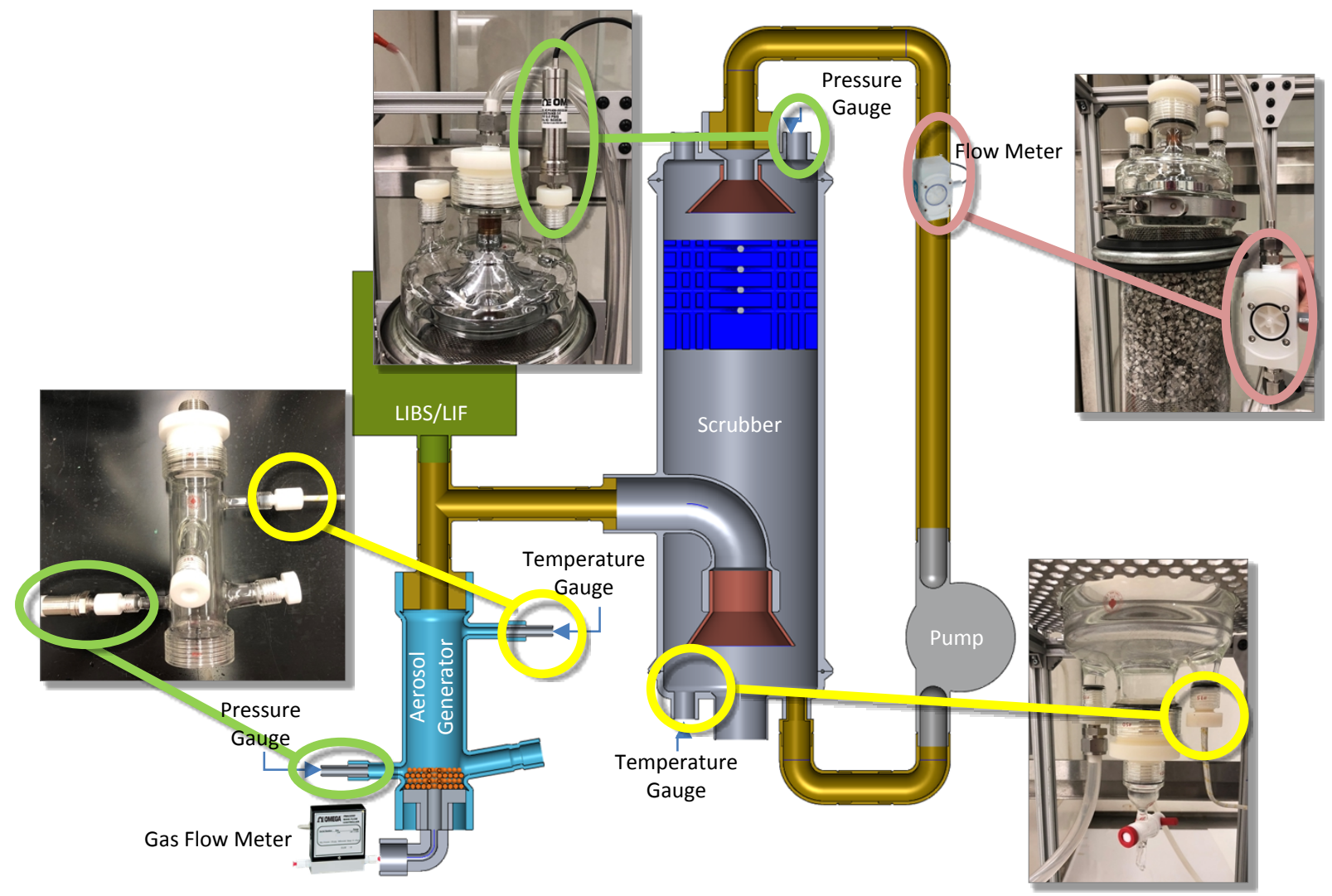

Figure 15. Illustration of instrumentation installation.

A pressure gauge was installed at the top of the of the scrubber and the side of the aerosol generator. The pressure at both points will be similar because this is a closed system, and the same pressure gauge can be used at both locations. Two temperature gauges were also installed at a single port on the scrubber and a single port on the aerosol generator. A K-type thermocouple meets the temperature requirements at both locations. A liquid flow meter was installed on the outlet of the pump and inlet of the scrubber, and a gas meter was installed on the outlet of the gas cylinder. The liquid flow meter will help researchers to understand the performance of the pump in reference to the output gas flow of the gas cylinders. Table 5 summarizes the instrumentation.

Table 5. Glass prototype instrumentation description.

\begin{tabular}{|l|l|l|l|l|}
\hline Instrument & Installation Location & Manufacturer & $\begin{array}{l}\text { Manufacturer } \\
\text { Part Number }\end{array}$ & $\begin{array}{l}\text { Operating } \\
\text { Conditions }\end{array}$ \\
\hline Pressure Gauge & $\begin{array}{l}\text { Scrubber (top port) } \\
\text { Aerosol Generator (side port) }\end{array}$ & OMEGA & $\begin{array}{l}\text { PX409- } \\
005 \mathrm{GUSBH}\end{array}$ & $\begin{array}{l}0-5 \text { PSI } \\
(1-1.3 \mathrm{bar})\end{array}$ \\
\hline Temperature Gauge & $\begin{array}{l}\text { Scrubber (bottom port) } \\
\text { Aerosol Generator (side port) }\end{array}$ & OMEGA & XC-14-K-24 & $0-1090{ }^{\circ} \mathrm{C}$ \\
\hline Liquid Flow Meter & Between pump and scrubber & OMEGA & FPR302 & $\begin{array}{l}0.1-10 \mathrm{GPM} \\
0.38-38 \\
\text { LPM }\end{array}$ \\
\hline Gas Flow Meter & Outlet of gas cylinder & OMEGA & FMA3106 & $\begin{array}{l}0-1000 \mathrm{SCM} \\
0-28,000 \\
\end{array}$ \\
& & & & LPM \\
\hline
\end{tabular}


A custom data acquisition software was created using National Instruments LabVIEW, see Figure 16. The current version of the software is capable of monitoring four thermocouples, two pressure sensors, and one flow sensor. The front panel contains a scrolling chart that displays the last 100 data points for the temperature(s), the flow, and the pressure(s) acquired. Also, the most recent measured value from the flow meter and pressure gauge(s) are displayed for fast real-time interpretation. This software is easily reconfigurable to acquire the signals from the LIBS/LIF and the Raman spectroscopy systems.

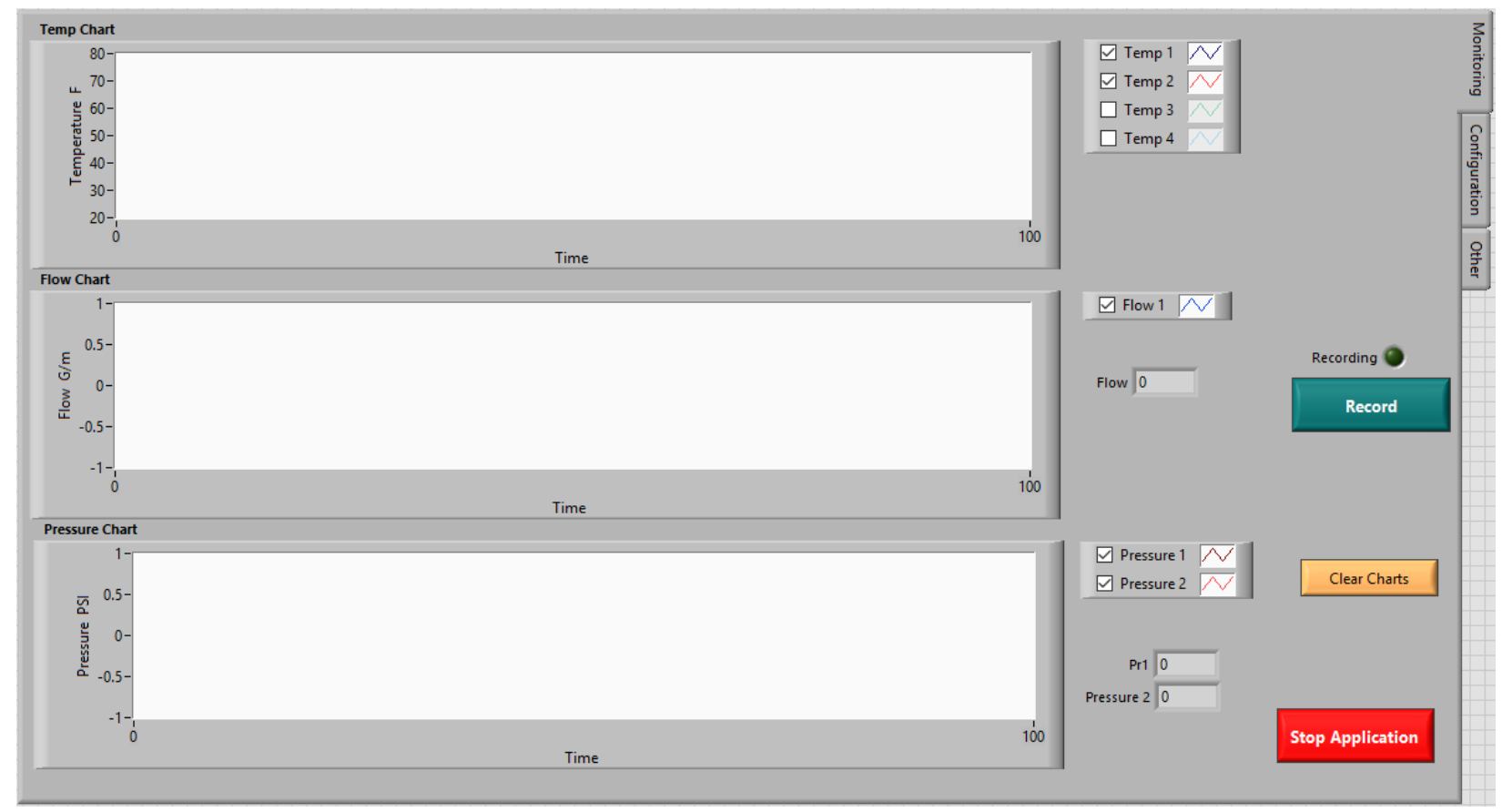

Figure 16. Screenshot of LabVIEW user interface for off-gas monitoring instrumentation.

A Measurement Computing USB-2408, 24-bit, $1 \mathrm{kS} / \mathrm{s}$, Temp/Voltage USB data acquisition device acquires the thermocouple and flow meter data (Figure 17), whereas, the pressure sensors communicate directly through USB visas. When the executable is first opened, the instrument data displays on the charts; however, data are not recorded until the "Record" button is pressed and the indicator is lit on the front panel. All measured signals are recorded and saved in a comma delimited file. The software samples and saves a data point every second. Since this is a fairly steady system, this sample rate is more than enough to capture changes in the measurement values. The program is closed by pressing the "Stop Application" button.

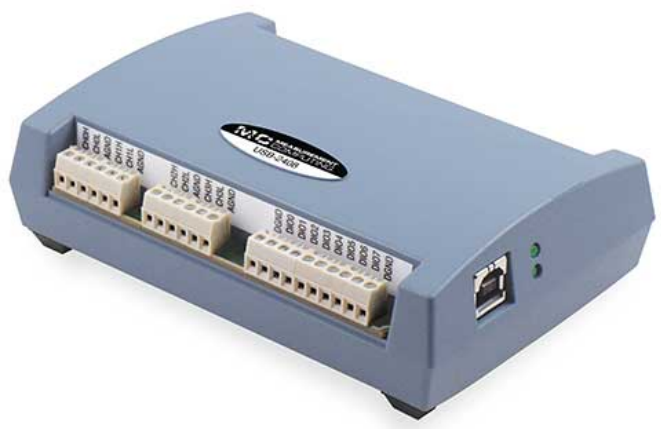


Figure 17. Image from measurement computer website for USB-2408 acquisition device.

\subsubsection{Stainless-steel design}

For an actual scrubber deployed on an MSR, a nickel alloy would be the construction material of choice as these have proven robust in caustic environments. As procurement of these alloys has a long lead time, stainless steel was considered as a possible short-term substitute for this project. Austenitic stainless steel (AISI304) can be passivated upon exposure to caustic, forming a protective layer of acicular iron or chromium compounds, ${ }^{39}$ albeit with changes in the distribution of iron and chromium in layers at the surface. ${ }^{40}$ However, after longer exposures, transpassivity leads to rapid formation of a thick layer of corrosion products, $\sim 7 \mu \mathrm{m}$, composed of precipitated hydroxides. For the purposes of demonstrating the utility of a molten hydroxide scrubber, the availability of the stainless steel has become an important consideration.

Figure 18 shows a drawing of the stainless-steel scrubber that will be used to contain the molten hydroxide eutectic. The design is very similar to the glass prototype, but the dimensions were adjusted to accommodate the physical properties of $\mathrm{NaOH}-\mathrm{KOH}$ versus water, as given in Section 2.2. Engineering calculations based on a Treybal analysis ${ }^{41}$ were used to optimize scrubber performance and the results are summarized in Table 4. The calculations assumed a packing factor of 540, with a nominal size of $15 \mathrm{~mm}$, to achieve a reasonable 0.4 bar pressure drop across the scrubber. The gas flow rate was assumed to be $5 \mathrm{~L} \cdot \mathrm{min}^{-1}$, and the liquid flow rate was $7 \mathrm{~L} \cdot \mathrm{min}^{-1}$. The viscosity of the $\mathrm{NaOH}-\mathrm{KOH}$ eutectic has not been well documented but was assumed to be $1 \mathrm{cp}$ for the sake of these calculations. The optimal size is highlighted in green. The red shows results that are not on the Treybal chart, and these conditions should be avoided.
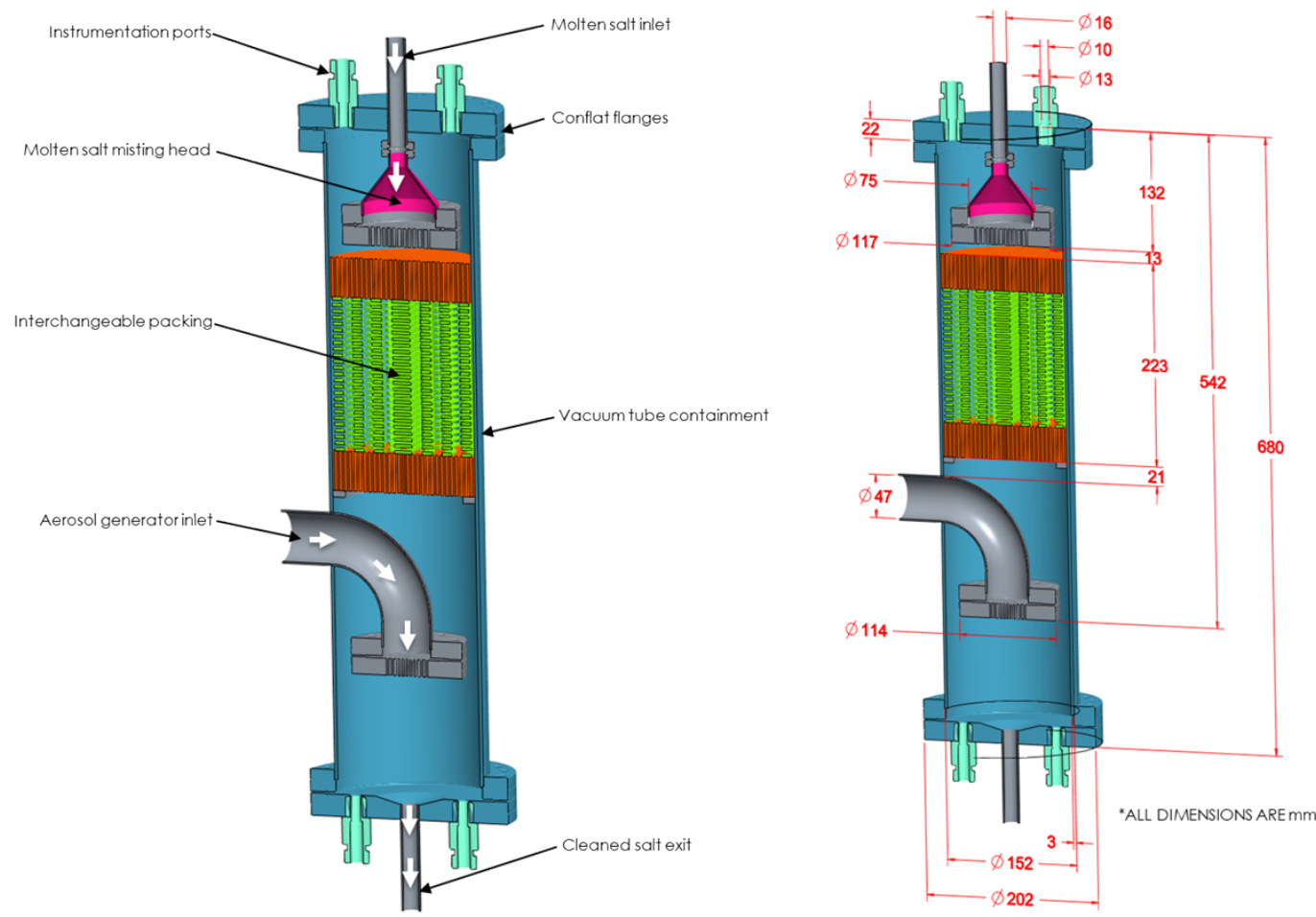

Figure 18. Stainless-steel scrubber design based on engineering flow calculations. 
Table 6. Engineering calculations column diameter for $15 \mathrm{~mm}$ size packing.

\begin{tabular}{|l|l|l|}
\hline $\begin{array}{l}\text { Column ID } \\
(\mathrm{cm})\end{array}$ & $\begin{array}{l}\text { Treybal Chart } \\
\text { Abscissa }(\mathrm{X})\end{array}$ & $\begin{array}{l}\text { Treybal Chart } \\
\text { Ordinate }(\mathrm{Y})\end{array}$ \\
\hline 8.0 & 7.86 & 0.00309 \\
\hline 9.0 & 7.86 & 0.00193 \\
\hline 10.0 & 7.86 & 0.00126 \\
\hline 11.0 & 7.86 & 0.00086 \\
\hline 12.0 & 7.86 & 0.00061 \\
\hline 13.0 & 7.86 & 0.00044 \\
\hline 14.63 & 7.86 & 0.00028 \\
\hline
\end{tabular}

Note: The red and green bands refer to optimal and off-scale parameters respectively. 


\section{DISCUSSION}

\subsection{Release limits for power reactors}

Gaseous radioactive effluents are primarily regulated by federal (as opposed to state) rules as airborne contamination can spread across state lines. Applicable regulations are located in four areas of the Code of Federal Regulations: 10 CFR 50 Appendix A, ${ }^{42} 10$ CFR 50 Appendix I ${ }^{43} 10$ CFR 20.1301, ${ }^{44}$ and 40 CFR $190.10^{45}$. While 10 CFR 50 Appendix A directly applies only to light water reactors, its criteria are intended to embody safety principles applicable to any reactor. The Nuclear Regulatory Commission released Regulatory Guide $1.232,{ }^{46}$ which provides equivalent wording applicable to advanced reactors. The criteria governing radioactive releases (60 and 64) from Regulatory Guide 1.232 and 10 CFR 50 Appendix A have identical purposes.

Criterion 60 of 10 CFR 50 Appendix A 60 requires plants to include a means to suitably control the release of radioactive materials during both normal operations and anticipated operational occurrences. Criterion 64 of 10 CFR 50 Appendix A requires the monitoring of radioactive releases from normal operations, anticipated operational occurrences, and postulated accidents throughout and around the plant.

10 CFR 50 Appendix I provides numerical guides for design objectives to meet as low as reasonably achievable objectives for radioactive materials in light water-cooled nuclear power plant effluents. Advanced reactors are expected to perform at least as well (typically, substantially better) than their light water predecessors. Appendix I stipulates that the reactor design applicant provide reasonable assurance that the annual total quantity of all radioactive material anticipated to be released from each light watercooled nuclear power reactor to unrestricted areas will not result in an annual air dose from gaseous effluents at any location near ground level, which could be occupied by individuals in unrestricted areas, in excess of $10 \mathrm{mrad}$ for gamma radiation or $20 \mathrm{mrad}$ for beta radiation.

10 CFR 20.1301 requires that each licensee conduct operations so that

(1) The total effective dose equivalent to individual members of the public from the licensed operation does not exceed $0.1 \mathrm{rem}(1 \mathrm{mSv})$ in a year, exclusive of the dose contributions from background radiation,

(2) The dose in any unrestricted area from external sources," ...", does not exceed 0.002 rem (0.02 millisievert) in any one hour.

40 CFR 190.10 requires that uranium fuel cycle operations be conducted in such a manner as to provide reasonable assurance that:

(1) The annual dose equivalent does not exceed 25 millirems to the whole body, 75 millirems to the thyroid, and 25 millirems to any other organ of any member of the public as the result of exposures to planned discharges of radioactive materials, radon and its daughters excepted, to the general environment from uranium fuel cycle operations and to radiation from these operations.

(2) The total quantity of radioactive materials entering the general environment from the entire uranium fuel cycle, per gigawatt-year of electrical energy produced by the fuel cycle, contains less than 50,000 curies of krypton-85, 5 millicuries of iodine-129, and 0.5 millicuries combined of plutonium-239 and other $\alpha$-emitting transuranic radionuclides with half-lives greater than one year.

10 CFR 100.11 Reactor Site Criteria also provides guidance on the accident performance of radionuclide retention reliability for the off-gas system. ${ }^{47}$ The MSR equivalent to the core melt described in the first footnote to 10 CFR 100.11 could be a major rupture of the cover gas system. Providing a robust, flexible secondary containment would prevent contamination of the remainder of the plant and challenging the external containment layer allowing the plant to employ "the expected demonstrable leak rate from the 
containment" (10 CFR 100.11 [a]) and still achieve essentially no radionuclide release to the environment.

\subsection{Off-gas functional requirements}

An MSR's cover gas (or off-gas) handling system has multiple functional requirements that reflect its key role in safe plant operations including waste handling. The system also serves as a mechanism to maintain knowledge of the location of radionuclides exiting the fuel salt circuit.

1) Prevent pressurization of the fuel salt circuit by providing a fuel salt expansion volume. As the salt expands with increasing temperature, the cover gas-handling system provides the expansion volume necessary to avoid a pressure spike within the fuel salt circuit. Also, the cover gas system provides the exit path for fission gases, preventing pressure build up over time. The key lower-tier requirements to prevent pressurization are adequate diameter piping to allow free flow of fuel salt volume surges due to rapid power/temperature rises and maintaining an unobstructed gas flow that is free from deposits arising from materials transported in the gas stream.

2) Contain radioactive materials emerging from surface of fuel salt. The cover gas system serves as the first barrier to mobile radionuclide release from the fuel salt circuit. The cover gas system performs this function by providing a mechanical barrier to release, converting some of the radionuclides in the cover gas to a less mobile form, and by holding the short-lived radionuclides sufficiently long to allow decay. The long-lived noble fission gas ${ }^{85} \mathrm{Kr}\left(t_{1 / 2}=10.8\right.$ years $)$ must be contained until decay. Note that ${ }^{85} \mathrm{Kr}$ could serve as a gradually increasing portion of the sparge gas used in the fuel salt circuit. However, xenon fission isotopes are strong neutron absorbers and would not be suitable for recirculating through the core of thermal spectrum MSRs. Continuing to provide radionuclide containment under accident conditions (i.e., following cover gas system leak or rupture) will likely entail employing a double containment system.

3) Strip materials suspended/contained within the cover gas stream into a stable waste form. The mists and vapors emerging from the fuel salt surface as well as tritium and noble gas decay products need to be removed from the cover gas system and converted to a form suitable for storage until decay.

4) Transfer decay heat generated within the cover gas to an ultimate heat sink during normal operations, anticipated operational occurrences, and postulated accident conditions. The cover gas system will have a substantial heat content. During normal operations, this can be rejected into a cooling system, such as through cooling the hydroxide salt passing through the scrubber. During a loss of power accident, the heat load within the system will initially be high but will decrease as no additional radionuclides are added to the system. The rate of decrease will depend on the portion of the heat load that derives from mists emerging from the fuel salt surface versus emerging fission gases.

5) Monitor the quantity and composition of radionuclides and fissile materials transferred from the fuel salt circuit and into each waste form. Compliance with both plant safety and safeguards requirements necessitates tracking the amount and composition of radionuclides leaving the fuel salt circuit. Radionuclide monitoring is required even following design basis accidents, so will need to include adequate back-up power.

6) Provide source of clean noble gas for in-containment use (sparging, sweep gas, seal lubrication, etc.). The cover gas handling system is the source of supply for the gas sparging system and as such, will return the cleaned cover gas to the in-containment process gas system.

7) Maintain near $100 \%$ system availability. 


\subsection{Progress toward conceptual design of an off-gas system}

In this first evaluation of an MSR off-gas, we chose to assess the use of a molten hydroxide scrubber because it should be able to remove much of the material that may be entrained in the headspace sweep gas. However, there are obvious exceptions, notably the xenon and krypton fission gases. These gases will decay and produce the daughters discussed in the introduction. The ionic species, such as iodine and cesium will also be easily trapped in the caustic; however, there may also be issues with trapping some of the daughters of xenon, such as tellurium. For instance, the conversion of tellurium(IV) into a soluble form, $\mathrm{TeO}_{3}{ }^{2-}$, is reported to take several hours, which will not be available in the off-gas system. ${ }^{48}$ This may be attributed to the difficulty of oxygen transport across phase boundaries, reported for molten salts. ${ }^{49}$ The interaction of fines of structural materials with the molten hydroxide scrubber must also be considered. For instance, graphite particles aerosolized in the headspace of the MSR may be able to react with the $\mathrm{NaOH}-\mathrm{KOH}$ molten salt, producing functionalized graphite particles that are water soluble. ${ }^{50}$ Such an assessment must be extended to each component of the off-gas system.

\subsection{ARE and MSRE experience}

Operational experience with MSRs is limited to the Aircraft Reactor Experiment (ARE) and MSRE, both of which experienced significant difficulties with their cover gas system. During the operation of the ARE "copious amounts of radioactive gas evolved from the reactor and escaped into the pit for a gas leak in the fuel pump." 51 The pit was not completely gastight (leaking fission gases into the occupied parts of the building), and "it became necessary to extemporize a gas pumping system by using compressed air jet pumps to pull a slightly negative pressure $\left(6-10 \mathrm{in} . \mathrm{H}_{2} \mathrm{O}\right)$ on the pits and to discharge the gas through a temporary 2-in. pipeline some $1000 \mathrm{ft}$ away from the building." 52

The MSRE fuel was circulated using a centrifugal pump that served additional purposes. The pump bowl was also the surge tank, the location where salt was sampled, the location where fuel salt (uranium fluoride) was added, the place where gaseous fission products were stripped with a flow of helium. Sampling and enriching were done with a sampler-enricher, which operated a remote carousel that could be evacuated or purged as necessary to maintain the integrity of the salt circulation system. More information about the pump bowl headspace and experience with gas sparging are provided by Engel et al. (1970). ${ }^{53}$

Four cover gas lines entered the pump bowl. Three of these were directed toward the bubblers or surge chambers that protected unheated gas supply lines in the event of a pressure excursion. The main line had a flow rate range of 1.5 to $5 \mathrm{~L} \mathrm{~min}^{-1}$, with a nominal flow of $2.4 \mathrm{~L} \mathrm{min.}^{-1}$. The gas then flowed to the offgas system through $12.5 \mathrm{~cm}$. lines for processing before being released to the atmosphere carrying salt mist and gaseous fission products.

Four percent of the pump discharge $\left(15.9 \mathrm{~L} \mathrm{~s}^{-1}\right)$ was reinjected at the top of the bowl through a spray ring designed to strip fission gases from the fuel salt. However, salt mist that was attributed to the action of the spray ring appeared in the pump bowl of MSRE. Tiny glassy beads of fluoride salts were observed in between flange faces, on filters, lines, and valves in the coolant off-gas system. However, the salt particles did not travel all the way to the particle trap that was positioned close to the vent house. The salt was estimated to be as low as $10^{-8} \mathrm{~g} \mathrm{~cm}^{-3}$ in the headspace, translating to the transport of $1 \mathrm{~g}$ of salt per month. The formation and transport of salt mists was not well understood. Other estimates ranged from $10^{-4} \mathrm{~g} \mathrm{~cm}^{-3}$ from the concentrations of uranium and ${ }^{95} \mathrm{Zr}$ in the pump bowl gas and $10^{-6} \mathrm{~g} / \mathrm{cm}^{3}$ from freeze capsules taken from the pump bowl.

The MSRE's pump shaft seal was slightly pressurized (to about 4 bar) between the top of the impeller shaft of the pump and the pump headspace. This resulted in-leakage of hydrocarbon seal oil. Other leakage occurred around various joints in the system. The MSRE also experienced issues with the oil from the pump being radiolytically polymerized, which contributed to plugging of the gas lines leading away from the pump bowl. Hydrocarbons tended to have gaseous fission products stick to them and in 
turn deposit on the particle filters thus clogging the system. The problem was substantially reduced by employing a larger (15 versus $10 \mathrm{~cm}$ diameter), redesigned particle trap. ${ }^{54}$

\subsection{Issues to be addressed}

The functional requirements listed above include considerations for a safe and effective off-gas system. Some of these design needs are listed below.

Design for decay heat removal. The heat load for an off-gas system must include dissipation of the decay heat of radionuclides passing through various components. In some cases, such as for the molten hydroxide scrubber, temperature control will be required for effective operation, and this may provide a means to control temperatures downstream. However, decay heat removal must also be effective in the event of a power failure and so passive heat loss must be included in the design.

Evaluation of the capabilities of the MSRE off-gas instrumentation and comparison with modern capabilities. As discussed in the context of MSRE, some elements that worked well, and some that did not. The MSRE provides a good starting point for an off-gas design, but we can learn from the experience of operators and designers and apply it to modern MSR reactor technologies.

Ability to clean/scrape out deposits in gas lines. Temperature gradients in the off-gas mean that salt mists, whether from the reactor or from the molten hydroxide scrubber, are apt to plate out in the piping that transports the gas from the headspace to the capture media. Maintenance of the off-gas system must include access to the gas lines through remotely operated tools to either remove deposits while online, allow replacement of components, or both.

Final waste form for the materials transferred to hydroxide. The hydroxide scrubber should capture most of the non-fission gas material that evolves from the MSR. The hydroxide must be converted into a stable high-level waste form.

Design for remote operations and maintenance due to high-radiation background. A topic that has experienced great strides in technological development since MSRE is remote sensing. However, the issue of hardened materials and electronics for remote sensors is an area of active research. Adaptation of tools used for extreme environments to monitor radionuclide loading, flow, materials performance, etc. will be a large part of the off-gas design.

Evaluation of advisability of secondary safety containment in the event of system leaks. Performance of the off-gas system under off-normal conditions must be considered. System leaks, even small, would be an example of such an event that may arise from the failure of materials in the system. The off-gas represents a route through which fission products can pass from the core to containment should a leak occur. So, the off-gas itself requires a secondary containment to prevent fission products from reaching containment. Instrumentation of the space around the off-gas piping and components would allow a breach to be quickly identified. Such a secondary containment may also be used to trap volatile tritium for fluoride salt reactors. 


\section{CONCLUSIONS}

MSR designs rely on an off-gas system with functional requirements that include the ability to provide a volume into which the salt can expand without pressurization of the reactor circuit; containment of airborne radionuclides and mists; stripping of the reactor headspace to a system that will capture and confine airborne radioactive materials with the flow of an inert gas; the detection and monitoring of concentrations of radionuclides in the headspace and elsewhere in the off-gas system; and a system to transfer decay heat from the off-gas into a reliable and stable heat sink. The off-gas project will study all of these aspects; however, this year's focus was the removal and stripping of airborne material and the detection and monitoring of radionuclides of interest, notably iodine as $\mathrm{I}_{2}$ and $\mathrm{ICl}$.

In particular, the following was achieved:

- Designed and commissioned a prototype glass scrubber, providing the basis for the design of hydroxide scrubber.

Why is this important? The glass scrubber provided a visual rendering of fluid versus gas flow during scrubber operation using existing packed-bed materials. The Teflon body piston pump for recirculating the fluid is the same one that will be used for the molten hydroxide scrubber. The glass scrubber has also served as a test bed for instrumentation, pressure, temperature, and flow transducers. Modeling and simulation of coarser packed-bed materials has started to ensure appropriate flow and no flooding in the design of the stainless-steel device. The prototype fabrication enabled a better understanding of possible flow issues and is a good demonstration system. The stainless-steel molten hydroxide scrubber that will operate at an elevated temperature is an important element of the proposed end-to-end off-gas system that will be developed in FY 2020. A model for the end-to-end off-gas system will be developed for reactor operation simulations.

- Installed monitoring instrumentation (pressure, flow, and temperature) and data acquisition software.

Why is this important? Scrubber performance will depend on the temperature and pressure drop across the packed bed, as well as flow rate of the fluid through the bed. The instrumentation will be used to monitor the operation of the hydroxide scrubber, as direct visual observation will no longer be possible, hence, the instrumentation has been developed to be as reusable as possible between systems. The data acquisition system will synchronize sampling of all the instrumentation, including spectroscopic analysis from each run.

- Developed a method for introduction of aerosols and mists into the scrubber.

Why is this important? Two designs are being investigated: one for powdered samples using a fluidized bed and one based on a fluid nebulizer. The generated aerosols will be characterized for particle size distribution and concentration using standard analysis methods. LIBS/LIF quantitative analysis can be tested using characterized airborne mists and aerosols.

- Analyzed iodine species, $\mathrm{I}_{2}$ and ICl, using Raman spectroscopy.

Why is this important? To enable quantitative analysis by Raman, a calibrated gas cell was developed and commissioned. Spectroscopic measurements used two separate excitation wavelengths that will allow better spectral resolution of complex airborne speciation. Success with quantitation means that Raman is a feasible method for monitoring the chemical form of a key fission product, iodine, in the off-gas. Quantitation was demonstrated for a range of temperatures and pressures. Monitoring for iodine will be needed to determine the performance of the scrubber design, in particular, and the off-gas system, in general. The technique will be extended to other species of interest. Spectroscopic analysis of aliquots from the hydroxide system will help to complete the mass balance for iodine and other species. 
- Installed the LIBS/LIF systems.

Why is this important? LIBS/LIF will enable the determination of elemental concentrations of airborne species in the off-gas, including vapors, mists, and particles. Data for vapors can be compared with Raman spectroscopy. LIBS/LIF will be coupled with the hydroxide scrubber to monitor the effectiveness of the molten hydroxide scrubber.

The off-gas program has been developing a molten hydroxide scrubber based on a recirculating $\mathrm{NaOH}-$ $\mathrm{KOH}$ eutectic. A glass prototype was built and tested to enable visualization of the operation of the scrubber. Instrumentation based on the LabView platform allows online monitoring of pressure, temperature and flow rate. A fluidized bed aerosol generator was built as part of the test apparatus for the scrubber. In addition, an impact nebulizer was tested to generate droplets representative of a mist found in the headspace of an MSR. The nebulizer was tested at room temperature but can be heated and configured to work at elevated temperatures with molten salts.

A gas measurement system was developed for the spectroscopic analyses of $\mathrm{I}_{2}$ and ICl using Raman spectroscopy. Laser excitation at $532 \mathrm{~nm}$ and $671 \mathrm{~nm}$ both provided quantitative results based on chemometric interpretation of spectral features in the mid-infrared. Having multiple excitation wavelengths gives the optical system greater flexibility in the detection of different species. Data taken at different wavelengths also allow results on phase behavior to be interpreted, which will be important in the analysis of complex chemical systems.

A LIBS/LIF apparatus and sample cell was designed and tested with the nebulizing aerosol generator. A sweep gas introduced into the chamber along with the nebulizer output showed containment of most of the mist in the central zone, with little escape through the opening for the LIBS/LIF probe.

These technologies will continue to be developed in the future, with the goal of incorporating the optical detection and monitoring into a complete end-to-end off-gas prototype system, to enable the assessment of the effectiveness of the off-gas system toward specific chemical species and radionuclides of interest. 


\section{ACKNOWLEDGMENTS}

This work was funded by the Department of Energy, Office of Nuclear Energy's Advanced Reactor Campaign. Pacific Northwest National Laboratory (PNNL) is operated by Battelle Memorial Institute for the Department of Energy under contract DE-AC05-76RL01830. This manuscript has been co-authored by UT-Battelle, LLC, under contract DE-AC05-00OR22725 with the US Department of Energy. 


\section{APPENDIX A}

\section{BILL OF MATERIALS}


Scrubber Bill of Materials

\begin{tabular}{|c|c|c|c|}
\hline Apparatus Component & Item & Supplier & Part Number \\
\hline Glass Scrubber & $\begin{array}{l}\text { Custom glass column } \\
\text { (see drawing) }\end{array}$ & ACE Glass & D164869 \\
\hline Glass Scrubber & $\begin{array}{l}\text { Nickel Rachid rings } \\
7.5 \mathrm{~mm} \times 0.38 \mathrm{~mm} \\
\text { wall Ni RR with frames }\end{array}$ & $\begin{array}{l}\text { Wisconsin Stamping } \\
\text { and Manufacturing }\end{array}$ & 295295265-NI \\
\hline Glass Scrubber & $\begin{array}{l}\text { Adapter, PFTE \#7- } \\
0.25 \text { in. NPT }\end{array}$ & ACE Glass & $5844-72$ \\
\hline Glass Scrubber & $\begin{array}{l}\text { Adapter, PFTE \#15- } \\
0.25 \text { in. NPT }\end{array}$ & ACE Glass & $5844-74$ \\
\hline Glass Scrubber & $\begin{array}{l}50 \mathrm{~mm}-225 \text { PFTE } \\
\text { bushing }\end{array}$ & ACE Glass & $7506-35$ \\
\hline Glass Scrubber & $\begin{array}{l}\text { Adapter, CAPFE, \#50- } \\
0.25 \text { in. NPT }\end{array}$ & ACE Glass & $5838-96$ \\
\hline Glass Scrubber & $\begin{array}{l}\text { Pneumatic Teflon } \\
\text { pump }\end{array}$ & White Knight & PSU030-12 \\
\hline Glass Scrubber & Nylon sheet for funnel & - & Machined at ORNL \\
\hline Aerosol Generator & $\begin{array}{l}\text { Custom glass column } \\
\text { (see drawing) }\end{array}$ & ACE Glass & D165161 \\
\hline Aerosol Generator & $\begin{array}{l}\text { ADAPTER, PTFE \#50- } \\
0.375 \text { in. NPT }\end{array}$ & ACE Glass & $5838-80$ \\
\hline Aerosol Generator & $\begin{array}{l}\text { Adapter, PFTE \#7- } \\
0.25 \text { in. NPT ( } 2 \text { of })\end{array}$ & ACE Glass & $5844-72$ \\
\hline Aerosol Generator & $\begin{array}{l}\text { Adapter, PFTE \#15- } \\
0.25 \text { in. NPT ( } 2 \text { of })\end{array}$ & ACE Glass & $5844-74$ \\
\hline Aerosol Generator & $\begin{array}{l}50 \text { mm-225 PFTE } \\
\text { bushing }\end{array}$ & ACE Glass & $7506-35$ \\
\hline Aerosol Generator & \#7 solid PTFE plug & ACE Glass & $5846-44$ \\
\hline Aerosol Generator & \#15 solid PTFE plug & ACE Glass & $5846-48$ \\
\hline Aerosol Generator & $\begin{array}{l}0.25 \text { NPT to } 0.25 \text { in. } \\
\text { Swagelok }\end{array}$ & Ridge Valve and Fitting & T-400-1-4 \\
\hline Aerosol Generator & Krypton 85 source & TSI Incorporated & 3077 \\
\hline Aerosol Generator & $\begin{array}{l}\text { Bronze powder } \\
-110+230 \text { mesh }\end{array}$ & Chemical Store.com & BZ4OP \\
\hline Aerosol Generator & $\begin{array}{l}\text { Glass fiber filters Type } \\
\text { A E }\end{array}$ & $\begin{array}{l}\text { Pall Laboratories/VWR } \\
\text { Scientific }\end{array}$ & $28150-192$ \\
\hline Aerosol Generator & $\begin{array}{l}\mathrm{TiO}_{2}, 1,500 \mathrm{~nm} \\
\text { powder, } 1 \mathrm{~kg}\end{array}$ & $\begin{array}{l}\text { US Research } \\
\text { Nanomaterials }\end{array}$ & US $1017 \mathrm{M}$ \\
\hline Stand & $\begin{array}{l}5 \text { of } 1 \text { in. } \times 4 \mathrm{ft} 8020 \\
\text { solid track }\end{array}$ & McMaster Carr & $47065 \mathrm{~T} 101$ \\
\hline Stand & $\begin{array}{l}12 \text { of } 1 \text { in. } \times 2 \mathrm{ft} 8020 \\
\text { solid track }\end{array}$ & McMaster Carr & $47065 \mathrm{~T} 102$ \\
\hline Stand & $\begin{array}{l}1 \text { of } 1 \text { in. } \times 1 \mathrm{ft} 8020 \\
\text { solid track }\end{array}$ & McMaster Carr & 47065T101 \\
\hline Stand & $\begin{array}{l}1 \text { of } 1 \text { in. } \times 11 \text { in. } 8020 \\
\text { solid track }\end{array}$ & McMaster Carr & $47065 T 801$ \\
\hline Stand & $\begin{array}{l}4 \text { square mounting } \\
\text { plates, } 3 \text { in.x } 3 \text { in. }\end{array}$ & McMaster Carr & $47065 \mathrm{~T} 651$ \\
\hline Stand & 24 braces & McMaster Carr & $47065 \mathrm{~T} 216$ \\
\hline
\end{tabular}




\begin{tabular}{|c|c|c|c|}
\hline Apparatus Component & Item & Supplier & Part Number \\
\hline Stand & 6 Tees & McMaster Carr & 47065278 \\
\hline Stand & $\begin{array}{l}1 \text { Panel, Al perforated, } \\
2 \mathrm{ft} \mathrm{sq.}\end{array}$ & McMaster Carr & 47065T901 \\
\hline Stand & 1 Panel, mesh, $2 \mathrm{ft}$ sq. & McMaster Carr & $47065 \mathrm{~T} 287$ \\
\hline Stand & 8 Panel hangers & McMaster Carr & $\begin{array}{l}47065 \mathrm{~T} 197 \\
847065 \mathrm{~T} 192 \\
\end{array}$ \\
\hline Stand & U-bolt for 2 in. pipe & McMaster Carr & $3176 \mathrm{~T} 36$ \\
\hline Stand & U-bolt for 6 in. pipe & McMaster Carr & $3176 \mathrm{~T} 43$ \\
\hline Stand & 4 end caps & McMaster Carr & 47065T91 \\
\hline Stand & 4 casters & McMaster Carr & $47065 \mathrm{~T} 83$ \\
\hline LIBS & $\begin{array}{l}\text { Mounted } 1050-1700 \\
\text { UVFS window } \\
2.75 \text { in. CF flange }\end{array}$ & Thorlabs & $\begin{array}{l}\text { VPCH42-C (anti- } \\
\text { reflection coating) } \\
\text { VPCH41 (no coating) }\end{array}$ \\
\hline LIBS & Lens tube & Thorlabs & SM1L30C \\
\hline LIBS & $\begin{array}{l}\text { Air-spaced lens, } \\
100 \mathrm{~mm} \text { focal length }\end{array}$ & Thorlabs & ACA254-100-1064 \\
\hline LIBS & $\begin{array}{l}\text { Assembly rods, } 2 \text { in. } \\
\text { long }\end{array}$ & Thorlabs & ER2-P4 \\
\hline LIBS & $60 \mathrm{~mm}$ cage plate & Thorlabs & LCP01/M \\
\hline LIBS & $\begin{array}{l}\text { SMA-to-SM1 fiber } \\
\text { adapter with } 0.5 \text { in. lens } \\
\text { mount }\end{array}$ & Thorlabs & CVH100-COL \\
\hline LIBS & $\begin{array}{l}0.5 \text { in. dia. UV fused } \\
\text { silica plano-convex } \\
\text { lense, } 20.1 \mathrm{~mm} \text { focal } \\
\text { length }\end{array}$ & Thorlabs & LA4647 \\
\hline LIBS & $\begin{array}{l}\text { flanges for } 1.5 \text { in. dia } \\
\text { tubing, with cap }\end{array}$ & McMaster Carr & $\begin{array}{l}9088 \mathrm{~K} 16 \\
9088 \mathrm{~K} 14 \\
\end{array}$ \\
\hline LIBS & $\begin{array}{l}\text { Conflat 6-way cube, } \\
\text { CF2.75 in., } 304 \mathrm{ss}\end{array}$ & Ideal Vacuum Products & P104786 \\
\hline
\end{tabular}




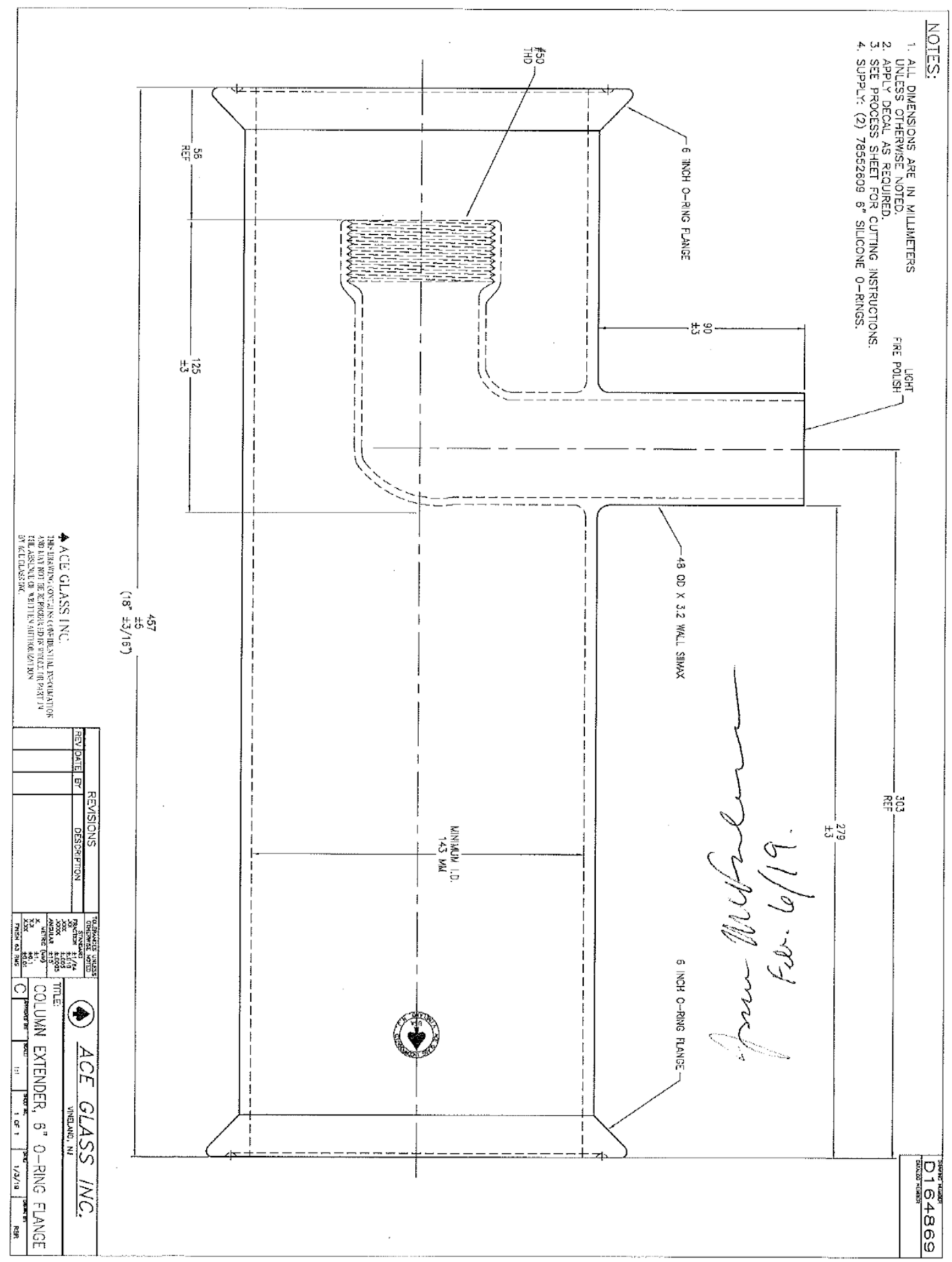

Glass scrubber prototype 


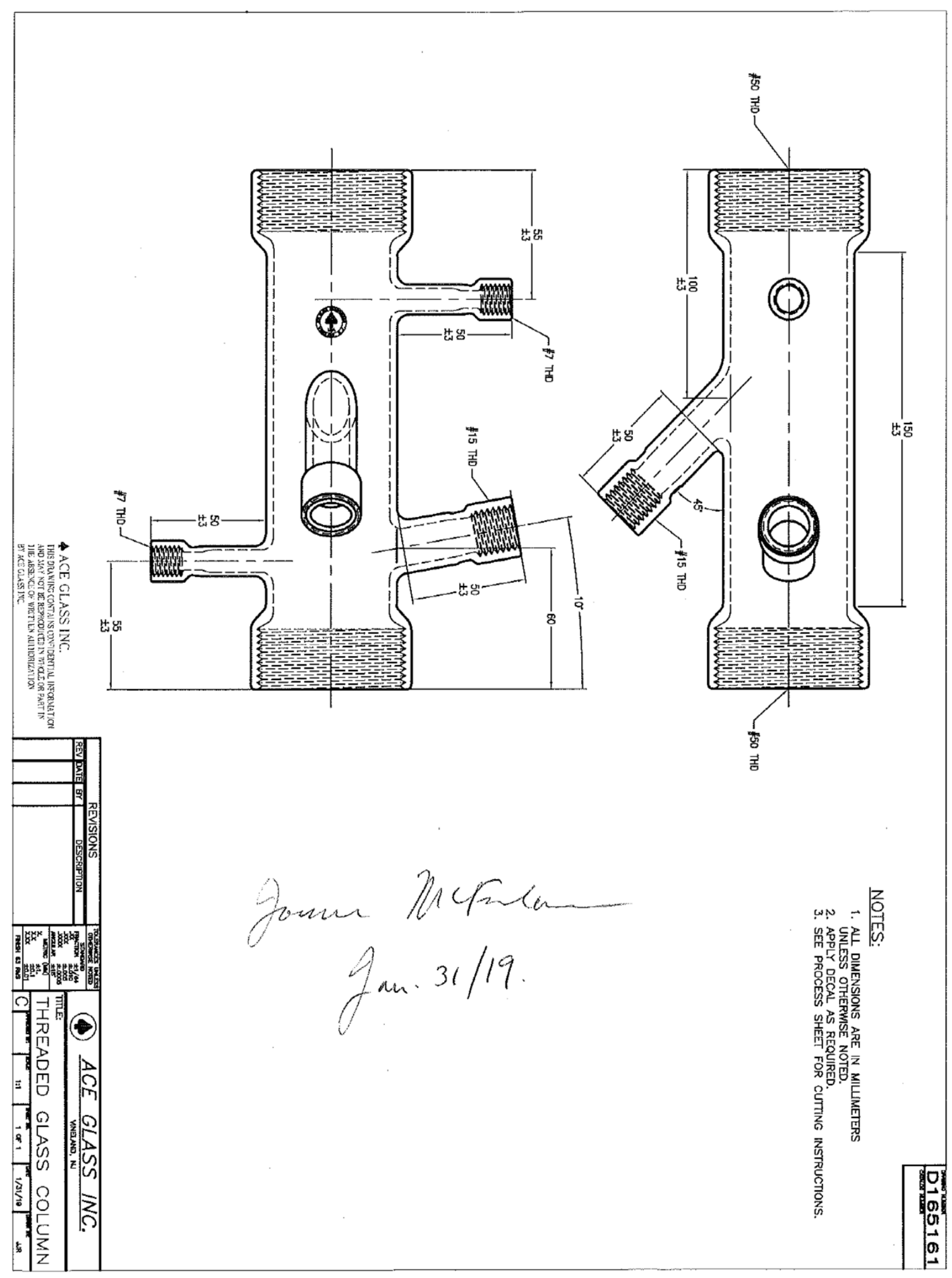


Fluidized bed aerosol generator 


\section{REFERENCES}

1. NRC SECY-08-130, Updated Policy Statement on the Regulation of Advanced Reactors, ML082261489.

2. Riley, B. J., J. McFarlane, G. D. DelCul, J. D. Vienna, C. I. Contescu, L. M. Hay, A. V. Savino, and H. E. Adkins. 2018. Identification of Potential Waste Processing and Waste Form Options for Molten Salt Reactors. NTRD-MSR-2018-000379, PNNL-27723. Pacific Northwest National Laboratory, Richland, WA, ORNL/TM-2018/958, Oak Ridge National Laboratory, Oak Ridge, TN.

3. Robertson, R. C. 1965. MSRE Design and Operations Report. Part 1. Description of Reactor Design, ORNL-TM-728, Oak Ridge National Laboratory, Oak Ridge, TN. p. 370.

4. Smith, G. P. 1956. Corrosion of Materials in Fused Hydroxides. ORNL-2048, Oak Ridge National Laboratory, Oak Ridge, TN.

5. IAEA. 1987. Design of off-gas and air cleaning systems at nuclear power plants. IAEA-Technical Reports.

6. R. C. Robertson, MSRE Design and Operations Report Part I Description of Reactor Design, Chapter 10 Cover Gas System and Chapter 12 Off-Gas Disposal System, ORNL-TM-728, Oak Ridge National Laboratory, Oak Ridge, TN.

7. Zagnit'ko, A. V., and Y. D. Chuvilin. 2009. "Nanoaerosols formation during the bubbling of lithium and beryllium fluorides molten salt to produce reactor radioisotopes." Nanotechnologies in Russia 4(11-12):851-56.

8. Vienna, J. D., E. D. Collins, J. V. Crum, W. L. Ebert, S. M. Frank, T. G. Garn, D. Gombert, R. Jones, R. T. Jubin, V. C. Maio, J. C. Marra, J. Matyas, T. M. Nenoff, B. J. Riley, G. J. Sevigny, N. R. Soelberg, D. M. Strachan, P. K. Thallapally, and J. H. Westsik. 2015a. Closed Fuel Cycle Waste Treatment Strategy. FCRD-MRWFD-2015-000674, PNNL-24114, Pacific Northwest National Laboratory, Richland, WA.

9. Bruffey, S. H., R. T. Jubin, and J. A. Jordan. 2016. "Capture of Elemental and Organic Iodine from Dilute Gas Streams by Silver-exchanged Mordenite." Procedia Chemistry 21:293-99.

10. Matyáš, J., G. E. Fryxell, B. J. Busche, K. Wallace, and L. S. Fifield. 2011. Functionalized silica aerogels: advanced materials to capture and immobilize radioactive iodine. In Proceedings of Ceramic Materials for Energy Applications: Ceramic Engineering and Science. eds. H-T Lin, et al., vol. 32, pp. 23-33, Wiley-The American Ceramic Society.

11. Riley, B. J., J. O. Kroll, J. A. Peterson, J. Matyáš, M. J. Olszta, X. Li, and J. D. Vienna. 2017a. "Silver-Loaded Aluminosilicate Aerogels as Iodine Sorbents." ACS Applied Materials \& Interfaces 9(38):32907-19.

12. Riley, B. J., J. Chun, W. Um, W. C. Lepry, J. Matyáš, M. J. Olszta, X. Li, K. Polychronopoulou, and M. G. Kanatzidis. 2013a. "Chalcogen-Based Aerogels as Sorbents for Radionuclide Remediation." Environmental Science \& Technology 47(13):7540-47.

.13 Riley, B. J., D. A. Pierce, W. C. Lepry, J. O. Kroll, J. Chun, K. S. Subrahmanyam, M. G. Kanatzidis, F. K. Alblouwy, A. Bulbule, and E. M. Sabolsky. 2015. "Consolidation of Tin Sulfide Chalcogels and Xerogels with and without Adsorbed Iodine." Industrial \& Engineering Chemistry Research 54(45):11259-67.

14. Baker, F. S., C. I. Contescu, C. Tsouris, and J. McFarlane. 2007. Activated carbon composites for air separation. ORNL/TM-2007/329, Oak Ridge National Laboratory, Oak Ridge, TN.

15. Liu, J., C. A. Fernandez, P. F. Martin, P. K. Thallapally, and D. M. Strachan. 2014a. "A Two-Column Method for the Separation of $\mathrm{Kr}$ and Xe from Process Off-Gases." Industrial \& Engineering Chemistry Research 53(32):12893-99. 
16. Subrahmanyam, K. S., I. Spanopoulos, J. Chun, B. J. Riley, P. K. Thallapally, P. N. Trikalitis, and M. G. Kanatzidis. 2017. "Chalcogenide aerogels as sorbents for noble gases (Xe, $\mathrm{Kr}$ )." ACS Applied Materials \& Interfaces 9(39):33389-94.

17. R. C. Robertson, Conceptual Design Study of a Single-Fluid Molten-Salt Breeder Reactor, ORNL4541, Oak Ridge National Laboratory, Oak Ridge, TN. June 1971

18. Compere, E. L., S. S. Kirslis, E. G. Bohlmann, F. F. Blankenship, and W. R. Grimes. 1975. Fission product behavior in the molten salt reactor experiment, Oak Ridge National Laboratory, ORNL-4865, Oak Ridge National Laboratory, Oak Ridge, TN.

19. NUCON Technical Bulletin 11B10. 2012. Noble Gas Delay Carbons. NUCON International Inc.

20. Stockinger, S. L. 2012. Nuclear Power Plant Gaseous Waste Treatment System Design Prepared for the American Society of Mechanical Engineers American Society of Mechanical Engineers Radioactive Waste Systems Committee.

21. IAEA. 1980. Separation Storage and Disposal of Krypton-85: Report of the Technical Committee on Separation, Storage, and Disposal of Krypton-85 Organized by the International Atomic Energy Agency. IAEA-Technical Reports.

22. NRC. 2012. "Chapter 7: Gaseous Radioactive Wastes.” In Radioactive Waste Management Technology, USNRC Technical Training Center 7-1 Rev. 0311.

23. M. Sturm, M. Schlösser, R. J. Lewis, B. Bornschein, G. Drexlin, and H. H. Telle. "Monitoring of All Hydrogen Isotopologues at Tritium Laboratory Karlsruhe Using Raman Spectroscopy”, Laser Physics, 2010, Vol. 20, No. 2, pp. 493-507.

24. D. Kirk Veirs and G. M. Rosenblatt, "Raman Line Positions in Molecular Hydrogen: $\mathrm{H}_{2}, \mathrm{HD}, \mathrm{HT}, \mathrm{D}_{2}$, DT, and $T_{2}$," Journal of Molecular Spectroscopy 121, 401-419 (1987).

25. D. G. Fouche and R. K. Chang, "Relative Raman Cross Section for $\mathrm{O}_{3}, \mathrm{CH}_{4}, \mathrm{C}_{3} \mathrm{H}_{8}, \mathrm{NO}, \mathrm{N}_{2} \mathrm{O}$, and $\mathrm{H}_{2}$ ", Appl. Phys. Lett. 20, 256 (1972)

26. D. G. Fouche and R. K. Chang, "Relative Raman Cross Section for $\mathrm{N}_{2}, \mathrm{O}_{2}, \mathrm{CO}, \mathrm{CO}_{2}, \mathrm{SO}_{2}$, and $\mathrm{H}_{2} \mathrm{~S}$," Appl. Phys. Lett. 18, 579 (1971).

27. A. Padilla, J. Perez, and A. C. Hernandez, "Isotropic Raman scattering of HF in dense gas and liquid $\mathrm{SF}_{6}$ : Study of the motional narrowing effect" J. Chem. Phys., 115, 20, 9427-9433 (2001).

28. Stammreich, H. and R. Forneris. Spectrochim. Acta 1961, 17 (8), 775.

29. Stammreich, H., R. Forneris, and Y. Tavares, Spectrochim. Acta 1961, 17 (11), 1173-1184.

30. Holzer, W., W. F. Murphy, and H. J. Bernstein, "Resonance Raman Effect and Resonance Fluorescence in Halogen Gases," J. Chem. Phys. 52, 399 (1970).

31. Hedderich, H. G., P. Bernath, and G. McRae, J. Mol. Spectrosc. 155, 384-392 (1992).

32. J. C. Malloy, Molten salt cleaning of engine components, Presented at the Production Engine Remanufacturers Association, January 26, 2016, Kolene Corp, Detroit, MI. www.kolene.com

33. H. W. Otto and R. P. Seward, Phase equilibria in the potassium hydroxide-sodium hydroxide system, J Chem Eng Data 9(4), 507-8 (1964).

34. Y. Takahashi, M. Kamimoto, Y. Abe, R. Sakamoto, K. Kanari, and T. Ozawa, Investigation of latent heat-thermal energy storage materials. IV. Thermoanalytical evaluation of binary eutectic mixtures of $\mathrm{NaOH}$ with LiOH or KOH, Thermochimica Acta, 121, 193-202 (1987). 
35. C. Dauby, J. Glibert, and P. Claes, Electrical conductivity and specific mass of the molten $\mathrm{NaOH}-$ KOH eutectic mixture, Electrochim. Acta 24, 35-39. (1979)

36. C. Dauby, J. Glibert, and P. Claes, Water and oxide ions concentration dependence of the specific mass and conductance of the molten $\mathrm{NaOH}-\mathrm{KOH}$ eutectic mixure, Electrochim. Acta 25, 1077-81 (1980).

37. P. Claes, Molten salts and fused oxides. L'Actualite Chimique 5, 10-15 (1999)

38. S. K. Sharm, C. K. Jotshi, and A. Singh, Viscosity of molten sodium salt hydrates, J. Chem. Eng. Data 29(3), 245-46 (1984).

39. P. C. Kuo and T. S. Tsai, New approaches to the synthesis of acicular $\alpha-\mathrm{FeOOH}$ and cobalt-modified iron oxide particles, J. App. Phys. 65, 4349-56 (1989).

40. B. Bozzini, F. Bogani, G. Giovannelli, S. Natali, G. Scarselli, and M. Boniardi, Corrosion of stainless-steel grades in $\mathrm{H}_{2} \mathrm{O} / \mathrm{KOH} 50 \%$ at $120^{\circ} \mathrm{C}$ : AISI304 austenitic and 2205 duplex, Materials and Corrosion, 64(11), 988-95 (2013).

41. Siebert, A. F. and J. L. Humphrey. 1995. Structured packings in liquid-liquid extraction, Sep. Sci. Technol., 30(7-9), 1139-55.

42. US Nuclear Regulatory Comission, Code of Federal Regulations, Appendix A to Part 50, General Design Criteria for Nuclear Power Plants, 10 CFR 50, https://www.nrc.gov/reading-rm/doccollections/cfr/part050/part050-appa.html

43. US Nuclear Regulatory Commission, Code of Federal Regulations, Appendix I to Part 50, Numerical Guides for Design Objectives and Limiting Conditions for Operation to Meet the Criterion "As Low as is Reasonably Achievable" for Radioactive Material in Light-Water-Cooled Nuclear Power Reactor Effluents, 10 CFR 50, https://www.nrc.gov/reading-rm/doc-collections/cfr/part050/part050appi.html

44. US Nuclear Regulatory Commission, Code of Federal Regulations, Subpart D - Radiation Dose Limits for Individual Members of the Public, 10 CFR 20.1301, https://www.nrc.gov/reading-rm/doccollections/cfr/part020/part020-1301.html

45. McMahon, K. A., N. E. Bixler, J. E. Kelly, M. D. Siegel, R. F. Weiner, K. A. Klein. 2010. Review of the technical bases of 40 CFR Part 190, Sandia National Laboratories, SAND2010-3757.

46. Mazza, J. 2018. US Nuclear Regulatory Commission, Regulatory Guide RG 1.232, Revision 0.

47. US Nuclear Regulatory Commission, Code of Federal Regulations, Determination of exclusion area, low population zone, and populations center distance, 10 CFR100.11, https://www.nrc.gov/readingrm/doc-collections/cfr/part100/part100-0011.html

48. P. Claes, Y. Dewilde, and J. Glibert, Chemical and electrochemical behavior in molten alkali hydroxides. Part V. Electrochemistry and chemistry of the chalcogens at oxidation state IV in the $\mathrm{NaOH}+\mathrm{KOH}$ (49 mol\%) eutectic mixture at 483 K. J. Electroanal. Chem. 282, 229-38 (1990).

49. P. Claes, Molten salts and fused oxides. L'Actualite Chimique 5, 10-15 (1999)

50. A. B. Bourlinos, V.Georgakilas, R. Zboril, D. Jancik, M. A. Karakassides, A.Stassinopoulos, D. Anglos, and E. P. Giannelis, Reaction of graphite fluoride with $\mathrm{NaOH}-\mathrm{KOH}$ eutectic, J. Fluorine Chem. 129, 720-24 (1980). 
51. T. Robinson, S. A. Reynolds, and H. W. Wright, Fission Product Investigations in ORNL-1864 Aircraft Nuclear Propulsion Project Quarterly Progress Report for Period Ending March 10, 1955, p. 13.

52. E. S. Bettis, R. W. Schroeder, G. A. Cristy, H. W. Savage, R. G. Affel, and L. F. Hemphill, The Aircraft Reactor Experiment-Design and Construction, Nucl. Sci. Eng., 2, 804-25 (1957)

53. Engel, J. R., P. N. Haubenreich, A. Houtzeel. 1970. Spray, mist, bubbles, and foam in the Molten Salt Reactor Experiment, ORNL-TM-3027, Oak Ridge National Laboratory, Oak Ridge, TN.

54. Guymon, R. H. 1973. MSRE Systems and Components Performance. ORNL-TM-3039, Oak Ridge National Laboratory, Oak Ridge, TN. 